\title{
Mariátegui antes de Mariátegui. El viaje a Italia y el fin de la «edad de la piedra», 1919-1923
}

\author{
Mariátegui before Mariátegui. The trip to Italy and the end of \\ «Age of the stone», 1919-1923
}

\author{
Gianandrea Nodari*
}

"Residí más de dos años en Italia, donde esposé una mujer y algunas ideas".

José Carlos Mariátegui

\begin{abstract}
Resumen: El objetivo del presente artículo es analizar a la compleja formación intelectual de Mariátegui, descubrir cuáles fueron las ideas que encontró en Italia, quiénes fueron sus referentes intelectuales y cómo influyeron en las futuras obras del autor peruano. El intelectual residió en Italia de 1919 a 1923, años claves en la reciente historia de la península caracterizados por la fundación del Partido Comunista Italiano y el surgimiento del movimiento fascista. En primer lugar, nos interesamos por el estudio de Mariátegui en su «edad de la piedra», o sea su fase juvenil caracterizada por la atracción hacia el decadentismo literario y un primer acercamiento a los problemas políticos y sociales de la sociedad peruana. En segundo lugar, analizamos las ideas y los puntos de vista de Mariátegui sobre los protagonistas políticos, intelectuales y culturales de la vida italiana de la época. Por último, nos concentramos en las herencias intelectuales de Mariátegui, tomando en consideración cinco intelectuales (Labriola, Croce, Gobetti, Gramsci e Tilgher) que, de manera diferente, influyeron sobre el pensamiento y el universo intelectual del peruano.
\end{abstract}

Palabras clave: Mariátegui, marxismo, socialismo, ideología, Latinoamérica, Italia

Abstract: This article focuses on the complex intellectual formative process of José Carlos Mariátegui. The aim is to discover the ideas underlying this process during his stay in Italy, identify his intellectual referents and how they influenced his political thinking. Mariátegui resided in Italy from 1919 to 1923, a period which can be considered key years for the recent history of Italy as the country saw the creation of the Italian Communist Party contemporary to the rise of the Fascist movement. My methodological approach will be firstly investigating what I call the "stone age" of Mariátegui, or his youthful phase characterized by his attraction towards decadence literary and a first introduction to the political and social problems of Peruvian society. Then I will analyze Mariátegui's ideas and points of view on the political, intellectual, and cultural protagonists of the Italian life of the time. Finally, I will focus on the intellectual inheritance of Mariátegui, taking into account five main intellectuals (Labriola, Croce, Gobetti, Gramsci and Tilgher) who -in a different way, influenced the thinking and the intellectual universe of the Peruvian Marxist.

Keywords: Mariátegui, marxism, socialism, ideology, Latin America, Italy.

Recibido: 26 julio 2017

Aceptado: 7 octubre 2017

* Italiano. Doctor en Historia por El Colegio de México (Colmex). Correo electrónico: gnodari@ colmex.mx 


\section{Introducción}

La experiencia italiana de José Carlos Mariátegui, el "primer marxista de América" como lo definió el profesor de literatura hispanoamericana Antonio Melis ${ }^{1}$, fue una etapa fundamental en su formación intelectual y política. Según el propio autor peruano su estancia en Italia, donde residió más de dos años, se caracterizó por un doble compromiso: se esposó con "una mujer" y con "algunas ideas". Objetivo de este artículo es hacer un acercamiento a la compleja formación intelectual de Mariátegui, descubrir cuáles fueron las ideas que encontró en Italia, quiénes fueron sus referentes intelectuales y cómo influyeron en las futuras obras del autor peruano.

Identificar de manera clara las influencias del intelectual pensador peruano no es un trabajo fácil. Como bien subraya el filósofo cubano Jaime Concha, para situar las influencias que se ejercen en Mariátegui:

Habría que trazar una cuádruple coordenada. Ella pasa por el pensamiento marxista europeo, desde Marx hasta Lenin, incluyendo a Kautsky, Hilferding y otros más; por las elaboraciones críticas filosóficas que conoce durante su estancia en Italia entre 1919 y 1923 (Croce y especialmente Gobetti); por una tradición del ensayo hispanoamericano desplegado entre Echevarría y Vasconcelos y, en fin, por una cadena de contribuciones locales que parte con Manuel González Prada, el indudable iniciador de la crítica moderna en Perú, rematando en la rica producción de los veintes ${ }^{3}$

El propósito de mi escrito es rescatar cuáles autores italianos, de qué manera y con qué consecuencias dejaron a Mariátegui una herencia cultural e intelectual, que podemos encontrar las obras del director de Amauta. A pesar de la acotación a las influencias italianas, el trabajo requiere una investigación detallada. En primer lugar, la bibliografía sobre el tema es muy limitada $\mathrm{y}$, aunque todos los escritos sobre Mariátegui subrayan la importancia de su experiencia en la península, pocos son los investigadores que han tratado de analizar esta temática de manera detallada y sistemática ${ }^{4}$. El mismo Robert París, probablemente el autor que mejor ha abordado el tema varias veces atribuye a Mariátegui las influencias más heterogéneas $\mathrm{y}$, negando el carácter marxista del pensador

\footnotetext{
${ }^{1}$ MELIS, "Mariátegui, primer marxista de América", en Cuadernos de cultura latinoamericana, N. 95, p. 6.

${ }^{2}$ La mujer en cuestión es Anna Chiappe, originaria de Siena. La frase fue escrita por Mariátegui en una carta enviada a Samuel Glusberg. Véase MARIÁTEGUI Siete ensayos de interpretación de la realidad peruana, p. 5. 3 Jaime Concha, "Mariátegui y su crítica al latifundio", en Revista Casas de las América, N. 140, 1983, La Habana.

${ }^{4}$ Más allá de la obra de Robert París, que sigue siendo el mejor trabajo acerca del tema; del análisis más literario de Antonio Melis y del texto de Ilán Meseguer que no se refiere en particular a Italia, sino más a las herencias "generales" de José Carlos; no he encontrado otros análisis importantes. Véase PARÍs, La formación ideológica de José Carlos Mariátegui; Melis, "Mariátegui, primer marxista de América", en Cuadernos de cultura latinoamericana, N. 95 e Illán Meseguer, José Carlos Mariátegui y su pensamiento revolucionario. Para un resumen sobre el contenido de estos trabajos, véase NúÑEZ, La experiencia europea de José Carlos Mariátegui y otros ensayos, pp. 7-37.
} 
latinoamericano, se limita a analizar a los pensadores que fueron recordados por el autor peruano en sus escritos, es decir, a Croce y Gobetti ${ }^{5}$.

Esta falta de un análisis puntual fue la primera motivación que despertó mi interés acerca del tema objeto de estudio. Pero hay, seguramente, otra causa que me empujó hacia el estudio de Mariátegui: su parcial o total desconocimiento en el contexto europeo ${ }^{6}$. Aunque las causas de esta indiferencia no son claras, creo que es un gran error no estudiar la riqueza y la complejidad del pensamiento mariateguiano en Europa y, sobre todo, en Italia. Esto porque la formación intelectual del peruano está íntimamente ligada a un periodo clave de la historia de la península, el de la primera posguerra, la fundación del partido Comunista Italiano y el surgimiento del movimiento fascista.

Volviendo al contenido del texto, para poder analizar la influencia de los pensadores italianos en Mariátegui, el ensayo se divide en tres apartados. En el primero, el análisis se concentrará sobre el Mariátegui de la «edad de la piedra», o sea la fase juvenil del intelectual peruano. Revisar los conocimientos y las inclinaciones de Mariátegui antes de su viaje a Italia es fundamental para descubrir en qué medida y de qué modo la experiencia en el extranjero modificó su visión. Por esto analizaré algunos de los primeros escritos de Mariátegui y pondré en evidencia acontecimientos históricos, tanto internos como externos a Perú, que influyeron sobre su visión del mundo en este primer periodo de formación. El segundo está dedicado a la experiencia italiana de Mariátegui. Los objetivos son investigar, por un lado, los eventos históricos que el peruano vivió de primera persona, por el otro analizar las primeras impresiones de Mariátegui sobre la nueva realidad que estaba viviendo. Por esto trataré de subrayar también sus ideas y puntos de vista sobre los protagonistas políticos, intelectuales y culturales de la vida italiana de la época. En el tercer capítulo me concentro en las herencias intelectuales de Mariátegui. Para ello, tomo en consideración cinco autores que, de manera diferente, influyeron sobre el pensamiento y el universo intelectual del peruano. El objetivo de este apartado es trazar un mapa intelectual de los intelectuales italianos que influyeron en la construcción de la ideología de Mariátegui y apreciar el contenido de "algunas ideas" que el intelectual peruano sacó de su experiencia italiana.

\section{Parte I \\ La «edad de la piedra»: el primer Mariátegui, 1894-1919}

El José Carlos Mariátegui de la «edad de la piedra» no era ciertamente un hombre privo de experiencias políticas y curiosidad intelectual. Nacido en Moquegua, pequeño puerto al sur de Perú, el 14 de junio de 18947, según el historiador Aníbal Quijano, la

\footnotetext{
${ }^{5}$ PARÍs, La formación ideológica de José Carlos Mariátegui.

${ }^{6}$ Según Melis la causa del "largo silencio de una figura excepcional como la de Mariátegui", se puede explicar con el enfoque más o menos "rígidamente eurocentrista" de la historiografía del movimiento obrero, véase MELIS, "El debate sobre Mariátegui: Resultados y problemas", en Revista de Crítica Literaria Latinoamericana, Año 2, No. 4, p. 124.

${ }^{7}$ Fue el segundo de tres hijos resultados del matrimonio entre Francisco Javier Mariátegui, limeño de familia terrateniente encumbrada, y María Amalia Achira, campesina del pueblo de Sayán en la sierra norte de Lima. Para un relato sintético de la biografía de Mariátegui, véase ZAPATA, Ideología y Política en América Latina, pp. 88-93.
} 
experiencia infantil de Mariátegui fue caracterizada de "pobreza, ausencia, enfermedad, inactividad física, soledad y melancolía, religiosidad y poética mística, inquietas e interrogadoras lecturas" 8 , hechos que influyeron profundamente en la futura producción intelectual del director de Amauta.

El Perú de la juventud de Mariátegui se caracterizó por el dominio político de la "república aristocrática" (1899-1919), conjunto oligárquico que, a pesar del control casi absoluto y prolongado del aparato político-institucional, fue capaz de crear un puente entre la sociedad colonial y la moderna ${ }^{9}$. La transición no estuvo exenta de contradicciones: exclusión política de la mayoría de la población y dominio del capital británico y estadounidense fueron el corolario del dominio oligárquico ${ }^{10}$. Control político y apogeo de la "economía de enclave" no impidieron el desarrollo de movimientos políticos y de protestas sociales, promovidas en particular por Nicolás de Perola, que en 1895 fundó el Partido Demócrata. Movimiento capaz de unificar gracias a una propaganda populista, burguesía comercial, terratenientes de la costa y sectores más radicales y populares, el Partido Demócrata representó el movimiento político más dinámico e innovador de la juventud de José Carlos ${ }^{11}$.

Es en este contexto que el joven Mariátegui empezó su carrera de periodista, trabajando en 1908 como obrero alcanza rejones en el periódico La Prensa. Desde esta fecha, Mariátegui comenzó a tejer una estrecha relación con un pequeño grupo anarquistas peruanos, frecuentando los locales de Luz y Amor, donde Manuel González Prada, "gran figura de intelectual burgués que preparó el terreno a las síntesis de Mariátegui y por primera vez trató el problema indio"12, daba sus conferencias. A pesar de este temprano acercamiento a la política, Mariátegui, entre 1910 y 1915, mantuvo viva su fe religiosa y en sus escritos que firmaba con el seudónimo de Juan Comiquear siguió siendo, según su propia definición, un "literato infectado de decadentismo y bizantinismo finiseculares"13.

\footnotetext{
${ }^{8}$ QUIJANO, Introducción a Mariátegui, p. 37.

${ }^{9}$ Según los historiadores Manuel Burga y Alberto Flores Galindo, la oligarquía al poder en la época de la República Aristocrática se caracterizó por ejercer un "dominio casi absoluto sobre la sociedad peruana, [...] excluyendo de la vida política a las grandes mayorías sociales”. Entre 1899 y 1912 se suceden al poder los gobiernos civilistas de López de Romana, Manuel Candamo, José pardo y Augusto B. Leguía. El acceso al poder de Guillermo Billinghurst en 1912, por 1 año y 4 meses, constituyó un breve interregno que terminó con un golpe militar de Oscar R. Benavides, quien dejó el poder a José Pardo (1915- 1919). Véase BuRGA y GALINDO, Apogeo y crisis de la República Aristocrática, p. 127.

${ }^{10}$ Según varios historiadores, esta situación tuvo como consecuencia la implementación de un capitalismo monopólico dominado por las burguesías extranjeras, que caracterizó el desarrollo peruano hasta el comienzo del siglo XX. Por ejemplo, fue entre 1895 y 1914 que se instalaron en Perú las primeras cuatro grandes corporaciones: Peruvian Corporation Ltd., Cerro de Pasco Corporation, International Petroleum Corporation y Grace, la primera con capital británico y las demás norteamericano. Véase QUIJANO, Introducción a Mariátegui, p. 17 y BURGA Y GALINDO, Apogeo y crisis de la República Aristocrática, p. 132.

11 A pesar de las sucesivas simpatías anarquistas, el Partido Demócrata fue el primer partido a despertar el interés político de Mariátegui. Véase Flores GALINDO, La Agonía de Mariátegui, p. 35.

${ }^{12}$ Según Antonio Melis fue casi inevitable que, en una situación pre-capitalista como la peruana, la difusión de las ideas socialistas europeas adquiriera "una matriz netamente anarquista, más bacuninista y proudhoniana que marxista". Véase MELIS, "Mariátegui, primer marxista de América", en Cuadernos de Cultura Latinoamericana, N. 95, pp.8.

${ }^{13}$ QuiJANO, Introducción a Mariátegui, p.36. También, según Diego Illán Meseguer, la primera época de la carrera periodística de Mariátegui fue caracterizada por una "predominancia de lo estético y [...] una
} 
Cabe mencionar que el contacto con Abraham Valdelomar, César Falcón y Félix del Valle, muy influidos por el d'annunzianismo y las corrientes futuristas, marcó los escritos juveniles de Mariátegui. Sin embargo, podemos apreciar en sus artículos un estilo original, influido por el futurismo de moda en la época y con un contendido que, moviéndose desde temas mundanos hacia los políticos, criticaba la vida social y cultural peruana. Aunque las invectivas de Mariátegui faltan de una base ideológica, la carencia era compensada por una fuerte carga ética y moral ${ }^{14}$. En el periodo que va de 1915 a 1919, una serie de acontecimientos, tanto a nivel nacional como internacional, desencadenaron que el joven literato decadente se transformara en un "demócrata radicalizado por elementos socializantes"15, donde la predominancia por la estética fue progresivamente absorbida por la crítica social ${ }^{16}$.

La situación interna peruana estaba pasando por un periodo de efervescencia. A fines de 1915 y principios de 1916 estalló en Puno el efímero levantamiento de Rumi Maqui. Un sargento mayor de caballería cuyo nombre original era Teodomiro Gutiérrez Cuevas, de formación al parecer anarquista, optó para apoyar a las masas campesinas y dirigir una gran rebelión. Aunque ésta fue descubierta en su inicio y fácilmente sofocada, la insurrección fue el descubrimiento para Mariátegui de las clases populares, en particular el encuentro con la "onda sísmica" de las masas indígenas. El joven periodista, en su columna diaria de El Tiempo escribió, el 25 de abril de 1917, que "la vida nacional" había llegado indudablemente a una etapa interesantísima, un verdadero "renacimiento peruano [...]: tenemos arte incaico. Teatro incaico. Música incaica. Y para que nada falte nos ha sobrevenido una revolución incaica"17.

La ola de protestas políticas no se suscitó solamente en el mundo campesino, mostrándose claramente en Lima, la capital del país. La creciente oposición en contra de la República Aristocrática aglutinó un número siempre creciente de clases sociales y no dejó indiferente al joven periodista, quien se comprometió más con la vida política activa. Consecuencia de este compromiso fue la renuncia a La Prensa y la creación de la revista Nuestra Época, cuyos redactores se agruparán en el Comité Organizador del Partido Socialista $^{18}$. De las páginas de este periódico, Mariátegui empezó a atacar al gobierno peruano por los excesivos gastos en la defensa armada y la indiferencia hacia el desarrollo de una política de trabajo y educacional. A causa de las fricciones con el director del periódico que no permitía "representar verdaderamente los ideales, tendencias y rumbos

\footnotetext{
preocupación por los temas religiosos y místicos”. Véase ILLÁN MESEGUER, José Carlos Mariátegui y su pensamiento revolucionario, p. 21.

${ }^{14}$ Véase, por ejemplo, los textos "Somos neutrales", “Candidatura liberal”, "La voz de Leguía” publicados en MARIÁTEGUI, Escritos juveniles. La edad de la piedra, pp. 57-63, 84-91, 95-98.

${ }^{15}$ ILlÁn MESEGUER, José Carlos Mariátegui y su pensamiento revolucionario, p. 39.

${ }^{16}$ Ya a mediados de 1916 Mariátegui y Falcón se separaron de La Prensa y se unieron al diario El Tiempo, periódico fundado por la oposición Leguísta contra el régimen de José Pardo (1915-1919), de orientación más izquierdista y que apareció por primera vez en Lima el 17 de junio de 1916.

${ }^{17}$ El Tiempo, Lima, año II, No. 288, 25 de abril de 1917, cit. en Flores GALINDO, La Agonía de Mariátegui, p. 41.

${ }^{18}$ Ya a mediados de 1918 Luís Ulloa, uno de los miembros más influyentes del periódico, propone convertir el movimiento intelectual en partido, pero Mariátegui y Falcón rechazaron esta propuesta. Véase QUIJANO, Introducción a Mariátegui, p. 35.
} 
doctrinarios que inspiran nuestra labor"19; Mariátegui y Falcón fundaron, en 1919, el periódico La Razón. En su primer número fechado el 14 de mayo, Mariátegui defendió enérgicamente la necesidad de una reforma universitaria apoyando el movimiento estudiantil de la Universidad de S. Marcos y tomó partido por el levantamiento de los obreros limeños, que el 13 de enero de 1919 marcharon por las calles de la ciudad pidiendo ocho horas de trabajo ${ }^{20}$.

No solamente fueron los eventos peruanos los que causaron un cambio progresivo en el pensamiento político de Mariátegui. En particular quiero aquí subrayar lo fuerte que lo marcaron episodios como la Revolución Mexicana de 1910 y la movilización estudiantil en Córdoba de 1918. Aunque no podemos medir el impacto de los acontecimientos mexicanos sobre Mariátegui en el periodo anterior a su viaje a Italia, sí podemos señalar que el peruano, en las páginas de Amauta, trató con interés este tema, subrayando la importancia de la Constitución carrancista de 1917, "que daba solución a dos problemas principales el problema de la tierra y el problema del trabajo" y criticando la deriva autoritaria del proceso revolucionario ${ }^{21}$. El director de la revista llamó la atención sobre la "actividad más revolucionaria y trascendente del gobierno Obregón", es decir su obra educacional, poniendo énfasis en la obra de José Vasconcelos, definido como "uno de los hombres de mayor relieve histórico de la América contemporánea, que ha dirigido una reforma extensa y radical de la instrucción pública"22.

Más que los hechos mexicanos, en este periodo Mariátegui, como la mayoría de los intelectuales peruanos, se interesó principalmente en el movimiento estudiantil. Este proceso, nacido en 1918 en la Universidad de Córdoba, universidad más antigua y símbolo de los rezagos coloniales en suelo argentino, alcanzó una dimensión mundial en poco tiempo, gracias a su llamado a la ruptura con el viejo mundo, con la dominación monárquica y monástica ejercida de la oligarquía en el ámbito universitario y societario. Los eventos de Córdoba se difundieron con increíble rapidez en toda América Latina. En la Universidad de S. Marcos en Lima, ya desde 1917, empezó a nacer un movimiento izquierdista, dirigido por Haya de la Torre, miembro de la Federación de Estudiantes de Perú. Las agitaciones universitarias despertaron el interés de Mariátegui que, a través de

\footnotetext{
${ }^{19}$ Después del ataque a los militares 1 teniente José F. Vásquez Benavides junto con otros jóvenes militares maltrató a Mariátegui en la redacción de El Tiempo que, después, desafió a duelo el mencionado teniente. Véase Illán Meseguer, José Carlos Mariátegui y su pensamiento revolucionario, p. 23.

${ }^{20}$ ILlÁN MESEGUER, José Carlos Mariátegui y su pensamiento revolucionario, p. 29.

${ }^{21}$ Véase el artículo escrito por Tina Modotti, "La contrarrevolución mexicana", en Amauta, N. 28, enero de 1930, y Esteban Pavletich, “La revolución mexicana, ¿revolución socialista?”, N. 26 febrero-marzo 1929.

${ }^{22}$ José Carlos Mariátegui, “México y la Revolución”, en Amauta, N. 18, octubre de 1928. Según Mariátegui, Vasconcelos fue capaz de encontrar una "una fórmula sobre pesimismo y optimismo que no solamente define el sentimiento de la nueva generación iberoamericana frente a la crisis contemporánea, sino que también corresponde absolutamente a la mentalidad y sensibilidad de una época". Véase "Pesimismo de la realidad y optimismo del ideal", publicado en Mundial, Lima, 21 de agosto de 1925, cit. en MARIÁTEGUI, El alma matinal y otras estaciones del hombre de hoy, p. 27. Mariátegui tuvo una actitud crítica con el proceso revolucionario y el movimiento laborista creado por Calles, una actitud la del presidente que, según el peruano, estaba contenido el proceso revolucionario a través de la creación de un movimiento obrero "archidomesticado". Véase "La reacción en México", publicado en Variedades, Lima, 15 de octubre de 1927, cit. en MARIÁTEGUI El alma matinal y otras estaciones del hombre de hoy, p. 35.
} 
artículos en el periódico La Razón, trató defender los ideales de los universitarios contribuyendo al conocimiento y el respaldo por parte de la opinión pública ${ }^{23}$.

Sin embargo, la atención del periodista peruano se concentró particularmente en la crítica hacia el gobierno del dictador Augusto Leguía, subido al poder por segunda vez en 1919 después de la experiencia de 1908 a 1912. La publicación de Mariátegui del artículo titulado "La patria nueva" en el periódico La Prensa, donde se definía a Leguía como "una persona senil y claudicante", jefe de un gobierno que trataba de "desviar el impulso del proletariado en una agitación chauvinista en contra de Chile" provocó el cierre del periódico y un mandato de arresto para el mismo Mariátegui y para Falcón, considerados por Leguía como "disociadores del orden público"24. A raíz de los vínculos familiares que unían a Leguía, esposo de la señora Julia Swayne Mariátegui, con José Carlos, el presidente de la República dispuso que ambos los periodistas fueran "expulsados" a Europa como "agentes de la prensa de Perú" 25 . El 8 octubre de 1919, los dos, custodiados por la policía, se embarcaron: Falcón con dirección España y Mariátegui a Italia ${ }^{26}$. Empezaba así el exilio dorado de José Carlos.

Una vez analizada esta primera etapa de la vida del intelectual peruano, ¿cómo podemos definir, en pocas palabras, las características de Mariátegui antes de su viaje Italia? Según Antonio Melis en el Mariátegui de la «edad de la piedra», no existe una clara contradicción "entre el primer periodo bohemio y la sucesiva toma de posición política clasista" 27 . Probablemente -a pesar de la gran diferencia entre el Mariátegui de las primeras batallas políticas y el del baile con la bailarina rusa Nora Rouskaya en el cementerio de Lima- la fase vanguardista de Mariátegui puede ser leída como una forma de protesta en contra de la angustia que generó en el joven periodista el ambiente en lo cual estaba actuando. Como visto, cuando Mariátegui se embarcó a Europa, su patrimonio político e ideológico ya tenía experiencias importantes. Claro, más allá de la lectura de varios libros y del interés por la vida política peruana, su conocimiento de teorías socialistas y sus planteamientos revolucionarios no estaban bien definidos y se mezclaban con "funambulismos surrealistas" 28 . En este sentido es importante subrayar la poca atención que

\footnotetext{
${ }^{23}$ Moretic, José Carlos Mariátegui. Su vida e ideario. Su concepción del realismo, p. 71.

${ }^{24}$ Según los historiadores Manuel Burga y Alberto Flores Galindo, el oncenio de Leguía, de 1919 a 1930 , "fue el intento sistemático, a veces temerario y maquiavélico de construir la "Patria Nueva" quitando el poder político a la antigua oligarquía civilista y entregando a un nuevo cuerpo que iba surgiendo y ampliándose a medida que avanzaba el proceso leguísta". Leguía intentó "reemplazar a las oligarquías imperantes por nuevas élites dispuestas a modernizar el país y obtener un despegue desarrollista". Sus planes políticos, en los primeros años, estuvieron dirigidos a quitar el poder político a las viejas clases dominantes: oligarquía costeña y gamonalismo andino; paralelamente desarrolló un ambicioso programa (burocracia, obras públicas, irrigaciones) destinado a crear una clase media adieta y obsequiante. Para lograr esto tuvo que entregar el país a la "influencia omnímoda del imperialismo norteamericano". Véase BURGA, FlorES GALINDO, Apogeo y crisis de la república Aristocrática, p. 140-144.

${ }^{25}$ QUIJANO, Introducción a Mariátegui, p. 41.

${ }^{26}$ Moretic, José Carlos Mariátegui. Su Vida e ideario. Su concepción del realismo p. 73 y RoulLON, Biobibliografía de José Carlos Mariátegui, p. XVII.

27 MELIS, "El debate sobre Mariátegui: Resultados y problemas", en Revista de Crítica Literaria Latinoamericana, Año 2, No. 4 (1976), p. 125.

${ }^{28}$ Ibid., p. 127.
} 
Mariátegui dedicó a la revolución bolchevique de $1917^{29}$. Con su viaje a Italia, esta falta de interés estaba destinada a cambiar.

\section{Parte II \\ Mariátegui en Italia: entre revolución y contrarrevolución, 1919-1923}

La estancia en Italia representó una etapa decisiva en la formación intelectual de Mariátegui. El peruano vivió en este país en una época crucial por su historia reciente. El periodo de 1919 a 1923 marcó un hito en la historia italiana del siglo XX: la crisis posbélica, el desarrollo del movimiento obrero y los intentos revolucionarios que tuvieron su más fulgida expresión en el bienio rojo, la gestación del fascismo y la marcha sobre Roma jugaron un papel crucial en la construcción del universo mariateguista. Al mismo tiempo fue en Italia donde Mariátegui entró en contacto directo con las diferentes corrientes del pensamiento marxista que caracterizaron la escena intelectual de Europa en la década de 1920. La época italiana fue entonces una escuela no solamente ideológica, sino también práctica para el joven intelectual peruano que participó activamente en procesos clave en la historia de la izquierda italiana ${ }^{30}$.

El 8 de octubre de 1919, Mariátegui se embarcó en el Callao con dirección a Europa. Arribó el 25 de diciembre al puerto de Génova y después de una breve estancia de dos meses en París, el peruano recurrió varias ciudades italianas: se instaló de enero a mayo de 1920 en Roma, luego en Florencia entre junio y julio, volvió a Génova en agosto para partir de nuevo hacia Venecia en septiembre, pasó por Turín, regresó a Roma en octubre de 1920 y residió en la ciudad eterna hasta comienzos de 1922. Para poder entender los primeros impactos que el ambiente italiano suscitó en Mariátegui, es necesario un análisis, aunque breve, de las Cartas de Italia. En esta serie de artículos, publicados en El Tiempo de Lima entre mayo de 1920 y el mismo mes, pero de 1922, están sintetizadas las impresiones que la península despertó en el director de Amauta.

Mariátegui fue un viajador atento y en sus cartas se puede apreciar a detalle la profundidad de sus comentarios, la pasión histórica, cultural y la sensibilidad que el paisaje itálico despertó en él ${ }^{31}$. Hablando del paisaje, Mariátegui aclaró que, para poder apreciar la naturaleza italiana libre de condicionamientos literarios, históricos e intelectuales, decidió ver la península sin un profundo conocimiento de su historia cultural, para poder mirar y

\footnotetext{
${ }^{29} \mathrm{~A}$ pesar del clima fuertemente anti-bolchevique que se respiraba en Perú en estos, con periódicos como Mercurio Peruano y El Comercio que definían el marxismo como "una economía siniestra plagadas de errores económicos fundamentales" y el bolchevismo como una "enfermedad oriental", Mariátegui se interesó poco a los eventos rusos. La única relación que podemos revisar fue a raíz de las gloriosas jornadas del 1 de mayo de 1919 en Lima, cuando escribió un artículo en donde relacionó las agitaciones huelguísticas latinoamericanas con la influencia bolchevique. Véase ILlÁN MESEGUER, José Carlos Mariátegui y su pensamiento revolucionario p. 30 y MoRetic, José Carlos Mariátegui. Su vida e ideario. Su concepción del realismo, p. 69.

${ }^{30}$ Como, por ejemplo, en el Congreso de Livorno que llevó a la creación del Partido Comunista de Italia (PC d'I) en 1921.

${ }^{31}$ Como bien menciona Estuardo Núñez, Mariátegui, espiritualmente, "se caló muy hondo en la vida social, en las complejidades de la política, en el conocimiento del arte antiguo y moderno, en la observación de los valores humanos, en la sugestión de las costumbres y en el sentido de la vita italiana en general. Véase NúÑEZ, La experiencia europea de José Carlos Mariátegui y otros ensayos, p. 23.
} 
analizar "con sus propios ojos, sin la lente ambigua y capciosa de la erudición" 32 . Fascinado por un paisaje y una naturaleza "teatrales y espectaculares" en grado de condicionar también la actitud del mismo pueblo italiano, descrito como dotado de "una teatralidad innata", el joven José Carlos analizó detalladamente todos los lugares que visitó, convencido de la necesidad de profundizar en estas ciudades "museos de reliquias y [...] de recuerdos" 33 . Roma, que no puede analizarse en singular porque "no existe una Roma, existen tres Romas: la Roma de los Césares, la de los Papas y la Roma de Víctor Manuel" 34 , Florencia, "vanidosa y coqueta como una mujer bonita" 35 , la belleza del cielo azul de Latium, los "dulces racimos de los castillos romanos, la miel de las abejas de oro de Frascati, la poesía sensual del paisaje de la égloga" tuvieron el efecto de "embriagar dionisiacamente" 36 los sentidos del joven periodista. La embriaguez del peruano no fue solamente dionisiaca, sino también política e ideológica.

Las consecuencias de la Primera Guerra Mundial y el periodo de la posguerra se caracterizaron, en Italia, por lo que Gramsci definió como "crisis orgánica"37. Crisis económica, con desempleo, hiperinflación, caída de la lira y un sistema "capitalista monopolista" que aumentó las diferencias socioeconómicas de la península ${ }^{38}$. Crisis política del estado liberal incapaz de mediar entre las diferencias instancias presentes en la sociedad y de controlar la radicalización del tejido social; ineptitudes que causaron la derrota del liberalismo a mano de un movimiento reaccionario como el fascismo. Crisis social, con la movilización del proletariado, que entre 1918 y 1920, se cristalizó en un protagonismo obrero sin precedentes ${ }^{39}$ y la contra-movilización de burguesía pequeña y mediana, que se acercó hacia el nuevo movimiento fascista, creado por Mussolini en $1919^{40}$.

\footnotetext{
${ }^{32}$ MARIÁTEGUI, “El paisaje italiano”, en Cartas de Italia, p. 65.

${ }^{33}$ MARIÁTEGUI, "El paisaje italiano", en Cartas de Italia, 67.

${ }^{34}$ MARIÁteGUi, El alma matinal, 73.

35 "Reflexiones sobre Florencia", publicado en El Tiempo, Lima el 2 febrero de 1921. Véase MARIÁTEGUI, Cartas de Italia, p. 211.

${ }^{36}$ Ibid., p. 147.

${ }^{37}$ Según Gramsci la crisis orgánica no es ni una crisis puramente económica, ni una específicamente política; de hecho, consiste en la contradicción entre las relaciones económicas preexistentes y la emersión de nuevas relaciones políticas, entre economía y política, entre "contradicciones" y "iniciativas", entre "estructura" y "sobrestructura", entre "cosmopolitismo de la vida económica" y "nacionalismo de la vida estatal". Véase GRAMSCI, Cuadernos de la Cárcel: los intelectuales y la organización de la cultura, p. 123.

${ }^{38}$ Las fábricas del triángulo industrial (Milán, Turín y Génova) se ligaron con el "quadrumvirato banquero" creando desequilibrios estructurales, aumentando las diferencias entre norte y sur y obligando las familias de campesinos meridionales a migrar hacia el norte. Para una descripción detallada sobre este periodo histórico véase SAlVATORELli MiRA, Storia d'Italia nel periodo fascista.

${ }^{39}$ Esto se concretó en más de 3500 huelgas y la creación, en junio-julio de 1919, de soviet en numerosas fábricas, con la tarea de controlar la producción, requisar los bienes de primera necesidad y redistribuirlos entre las familias más pobres. Para un análisis detallado, véase DETTI, "Protagonisti e alternative del Biennio Rosso", en Studi Storici, Anno 13, No. 1 (Jan. -mar., 197), pp. 191-198 y ProcACCI, "Popular protest and Labour Conflict in Italy, 1915-1918”, en Social History, Vol. 14, No. 1 (Jan. 1989), pp. 31-58.

${ }^{40}$ Estos sectores, en el periodo de guerra había vivido un gran prestigio, cancelado por la crisis inflacionaria y el desempleo. Frustración económica y descenso social causaron un resentimiento en contra del proletarito y de la gran burguesía ("los tiburones"), culpable de, egoísmo por haber aprovechado de la crisis de posguerra para aumentar su riqueza personal. Consecuencia política de este malestar fue la falta total de confianza hacia la clase dirigente liberal y un acercamiento al fascismo. Véase SALVATORELli-Mira, Storia d'Italia nel periodo fascista, pp. 22-25.
} 
Las primeras reflexiones de Mariátegui se relacionaron con dos hechos ya presentes en su agenda intelectual durante la época peruana: el futurismo y los movimientos sociales con matriz religiosa. La figura de Gabriele D'Annunzio y su Impresa di Fiume ${ }^{41}$, impresionaron al peruano. Una vez en Italia, Mariátegui diferenció el futurismo de las demás escuelas o arte vanguardia, resaltando cómo el futurismo era una "cosa peculiar de la vida italiana", que aspiraba a ser no solamente un movimiento de renovación artística, sino también un movimiento de renovación política; es decir, se caracterizó por ser un “impetuoso y complejo afán de renovación"42. El vate D'Annunzio fue descrito por Mariátegui como un "hombre inquieto, con tanta imaginación como dinamismo, que no puede amar el aislamiento aristocrático y eremítico de la torre de Marfil", entonces diferente y mejor de los demás poetas que viven "afuera del tiempo y del espacio" 43. Mariátegui, bajo influencia de Sorel, subrayó que lo fundamental de la impresa fiumana no era la ideología que casi siempre es lo "menos concreto, lo menos precisos, lo menos vigoroso"; sino lo fundamental era "la acción"44.

Otro personaje que llamó la atención de Mariátegui fue Don Luigi Sturzo, cura exponente del catolicismo "social y democrático" y creador del Partido Popular Italiano (PPI), fundado en 1919 con el objetivo de crear un movimiento católico que pudiera representar los intereses del mundo obrero y de las clases medias moderadas ${ }^{45}$. Partido prevalentemente campesino, y con fuerza en las áreas menos industrializadas del país, su programa tenía dos puntos básicos: respeto hacia la propiedad privada; reforma agraria y del sistema fiscal por una "más ecua redistribución de las tierras y de los salarios" y, en general, una mayor justicia y mayor autonomía social ${ }^{46}$. Fue en particular la obra organizadora "inteligente e moderna" de Sturzo, que plasmó la organización de sindicatos y federaciones católicas sobre la base de un partido con base socialista y cristiana, a permitir, según el peruano, la construcción de una sólida base popular ${ }^{47}$. Descrito por Mariátegui como "curita menudo, nervioso, activo y meridional, tan práctico e idealista, tan flexible y firme al mismo tiempo, [...] ecléctico, sagaz, persuasivo" "48, Don Sturzo, señaló el peruano, percibió la necesidad de unificar las diferentes animas del "espiritualismo cristiano"

\footnotetext{
${ }^{41}$ Ocasión en la cual el poeta guio un grupo de 2600 rebeldes del ejército real italiano a la conquista y a la creación, en 1920, de un estado independiente en Fiume, ciudad contendida entre Italia y Yugoslavia, exasperando el revangismo nacionalista y favoreciendo, de manera indirecta, el discurso revisionista de Mussolini.

42“Marinetti e il futurismo", MARIÁTEGUI en La escena contemporánea, p. 186.

43 "D’Annunzio después de la epopeya", Roma, marzo de 1921, publicado por El tiempo, Lima, 5 de junio de 1921. Véase MARIÁTEGUI, Cartas de Italia, p. 95.

${ }^{4}$ Ibid., p. 96.

${ }^{45}$ Partido prevalentemente campesino y con fuerza en las áreas menos industrializadas del país, su programa tenía tres puntos básicos: respecto de la propiedad privada que tenía que proteger y respetar la solidaridad social; reforma agraria y del sistema fiscal por una redistribución justa de las tierras y de los salarios; mayor justicia social. Véase AlATRI, "Luigi Sturzo nel centenario della nascita", en Studi Storici, No.1 (Jan-mar., 1972), p. 202.

${ }^{46}$ ALATRI, "Luigi Sturzo nel centenario della nascita”, en Studi Storici, No.1 (Jan-mar., 1972), p. 202.

47 "El Partido Popular Italiano", Roma, 28 de marzo de 1920, publicado en El Tiempo el 15 de septiembre de 1920. Véase MARIÁTEGUI, Cartas de Italia, p. 59.

48 Ibid., p. 60.
} 
permitiendo juntar aristócratas, burgueses, curas y obreros bajo la misma lucha en contra del materialismo maximalista ${ }^{49}$.

Asimismo, las vicisitudes del movimiento obrero y del partido socialista fueron analizadas por Mariátegui, que, en contacto con algunos del movimiento más importante socialista de la época, pudo vivir en persona los eventos de Turín. La "Petersburgo de Italia" fue la ciudad en donde los intelectuales pensaban y operaban, ciudad industrial y proletaria, donde los obreros trataban de conseguir un nuevo orden; ciudad que estaba viviendo al comienzo de los veinte una situación que el comunista Palmiro Togliatti definió como "un extraordinario Sturm und Drang"50. En 1920, después de la ocupación de la fábrica de la Alfa Romeo por parte de los trabajadores de la Federazione Italiana Operai Metallurgici (FIOM), la revolución pareció una cuestión al orden del día; y fue Turín el epicentro de este movimiento, también desde el punto de vista intelectual. Aquí tenía su centro el grupo de Ordine Nuovo, cuyos miembros (entre los otros Togliatti, Terracini, Gramsci y Tasca) serán, pocos años después, protagonistas de la creación del Partido Comunista de Italia. El protagonismo obrero creó tensiones en la misma izquierda, representada por el Partido Socialista, dividido entre revolucionarios, maximalistas y reformistas ${ }^{51}$.

En el debate interno del socialismo italiano, Mariátegui tomó parte por el ala revolucionaria del partido, el ala ordinovista, criticando el método "teóricamente revolucionario pero prácticamente reformista" de la cúpula del partido socialista cuya burocratización y pragmatismo impedían la toma de conciencia del "nuevo espíritu socialista que estaba madurando en Italia" ${ }_{52}$. Por esta razón, el intelectual peruano saludó con entusiasmo la escisión del Congreso de Livorno, en la cual él participó, entre las dos ánimas del partido; escisión que dio origen al Partido Comunista de Italia que, como subrayó Mariátegui, optó claramente por "el método revolucionario" 53 . Adelante revisaremos que también sobre el fascismo, la perspectiva de Mariátegui se construyó alrededor de la visión de los intelectuales del Ordine Nuovo. Descrito como movimiento de la pequeña burguesía, financiado por el capital industrial y agrario, el fascismo según

\footnotetext{
49 Ídem.

50 Togliatti, Il Partito Comunista Italiano, p. 34.

${ }^{51}$ Esta crisis interna llevó a la expulsión de los reformistas, con Turati, Modigliani e Treves que fundaron el Partido Socialista Unitario (PSU), con Matteotti como secretario y la minoría del viejo partido socialista que decidió separarse de los maximalistas por dar vida al Partido Comunista de Italia (PCd'I). La descomposición de la izquierda favoreció la subida de Mussolini, que tenía todas las características necesarias por una toma del poder: el estado ya no controlaba el orden público, el congreso era paralizado a causa de sus divisiones internas, la oposición socialista y liberal no tenía la fuerza para controlar la subida fascista. Con la marcha sobre Roma, del 28 octubre de 1922, los fascistas marcharon sobre la capital, y el rey Victorio Emanuel III expresó su rechazo a reprimir la revuelta con el ejército, decidiendo de asignar a Mussolini la tarea de reorganizar un nuevo gobierno. El nuevo aparado fascista posible gracias al apoyo del rey, de la burguesía industrial, de los grandes latifundistas, de las clases medias, la ayuda indirecta de la iglesia y el apoyo militar dio así comienzo a una dictadura agresiva y autoritaria, destinada a terminar solamente el 25 de abril de 1945.Véase Salvatorelli -Mira, Storia d'Italia nel periodo fascista, pp. 10-15.

52 MARIÁTEGUI, La Escena contemporánea, p. 137.

${ }^{53}$ Ibid., p. 61
} 
Mariátegui tuvo el papel de "anti-revolución o, como se prefiere llamarla, contrarevolución" ${ }^{\prime 4}$.

Las observaciones analizadas sobre el movimiento católico, el movimiento socialista y el futurismo, junto con el interés sobre personajes políticos italianos claves en la época de la primera posguerra nos dan una imagen global de la riqueza y articulación del análisis de Mariátegui sobre la vida italiana ${ }^{55}$. En síntesis, podemos decir que el viaje a Italia fue, por Mariátegui, fundamental: fue en la península que el joven intelectual peruano refinó su cultura autodidacta, se liberó de sus estetismos de la «edad de la piedra», conoció de muy cerca algunos de los personajes más importantes en la vida cultural italiana de la época, entre los cuales Croce, Gobetti, Gramsci e Adriano Tilgher tuvieron un gran impacto en su desarrollo intelectual.

\section{Parte III \\ Las herencias intelectuales de Mariátegui:}

\section{Labriola y Croce: los "maestros" marxistas de Mariátegui}

La primera herencia intelectual que quiero subrayar es la que relaciona a Mariátegui con Arturo Labriola y Benedetto Croce. Esta relación no es novedosa, sin embargo los autores que trabajan el pensamiento de Mariátegui no suelen destacarla ${ }^{56}$. Hemos decidido retomar este análisis principalmente por dos motivos. El primero está relacionado con la visión parcial que los trabajos mencionados ofrecen acerca de la influencia de los dos filósofos italianos, en particular de Labriola. Robert París, con razón, subraya que lo aprendido por Mariátegui en Italia fue "esencialmente un método -el marxismo- pero de cierto estado del marxismo, tal como se lo practica y se lo difunde en la Italia de la posguerra" 57 y atribuye esta enseñanza a la obra de Croce. Melis trata matizar esta influencia. El literato italiano sostiene que, "aunque Croce constituyó para Mariátegui un punto de referencia constante", el intelectual peruano siempre subrayó de manera clara cómo "las calificaciones ideológicas y políticas del filósofo napolitano era divergentes de la suya" 58 . A pesar de las diferentes interpretaciones ninguno de los dos autores profundiza en los contenidos de esta influencia. Melis habla de la importancia del "idealismo crociano" en la formación marxista de Mariátegui, París se enfoca más sobre las relaciones entre Croce y Sorel y en cómo el ingeniero francés tuvo una gran influencia sobre el peruano,

\footnotetext{
54 Ídem. Véase también, para un análisis de Mariátegui sobre el fascismo, "Los ideólogos de la reacción”, en Defensa del marxismo, pp. 115-119.

55 Por ejemplo, el jefe de Gobierno Francesco Saverio Nitti, cuyo ecleptismo típico de una generación "agnóstica, pragmática, fría y heterodoxa" fascinó Mariátegui y Giovanni Amendola, del cual Mariátegui evidencia la "fe honesta y militante en un liberalismo y un ideal de Democracia que es definida como quimérica e impotente. Véase MARIÁTEGUI, La Escena contemporánea, pp. 61 y 68.

${ }^{56}$ Me refiero a Robert París que trata el tema en el apartado "Una revisión del marxismo", en La Formación ideológica de José Carlos Mariátegui, pp. 122-153, Antonio Melis, "Mariátegui, primer marxista de América", en Cuadernos de cultura latinoamericana N.95, y NuÑEZ que en La experiencia europea de José Carlos Mariátegui y otros ensayos retoma el análisis de París.

${ }^{57}$ PARÍs, La Formación ideológica de José Carlos Mariátegui, p. 80.

${ }^{58}$ MELIS, "Mariátegui, primer marxista de América” en Cuadernos de cultura latinoamericana N.95, p. 122.
} 
concluyendo que la herencia más importante heredada por el director de Amauta fue la técnica marxista y el acercamiento al "pensamiento de Sorel" ${ }_{59}$.

La segunda laguna que se puede notar en estas interpretaciones "clásicas" es la falta de un análisis puntual sobre Labriola. A pesar del hecho de que París individua puntos de contacto entre lo que puede ser considerado como el padre del marxismo italiano y Mariátegui ${ }^{60}$, Labriola no aparece como protagonista en la formación intelectual del peruano. Esto nos parece un grave error, tanto porque Mariátegui conocía la obra de Labriola como porque la formación marxista de Croce fue consecuencia de su relación con Labriola que, siendo su profesor universitario, lo incitó a escribir sobre el tema del marxismo entre el 1895 y el $1898^{61}$. Por tal razón, en mi análisis trataremos de escudriñar las herencias del marxismo de Labriola y Croce en Mariátegui ${ }^{62}$ subrayando sobre todo las influencias del labriolismo en el joven peruano.

Podemos distinguir por lo menos tres elementos de la concepción marxista de Croce y Labriola que influyeron en el pensamiento de Mariátegui, en el orden: el papel de la economía y de la historia en el marxismo, la importancia de la dimensión ética en la política y el rol de la educación en la clase trabajadora. Elementos que contribuyeron a formar el núcleo una nueva interpretación marxista, definida por el mismo Labriola como "marxismo latino" "63. Ahora bien, ¿en qué consiste este tipo de marxismo?

Labriola, primer intelectual italiano que se acercó a la filosofía marxista, se caracterizó, tanto en su carrera académica como en la actividad política activa, por la búsqueda de un marxismo de matriz diferente respecto a la versión dogmática muy en boga en los países centroeuropeos. Su paso de una idea liberal a una socialista se explicó por motivos de "naturaleza política, pedagógica y cooperativa" y por su obra educacional hacia obreros a los cuales dictaba clase sobre derechos y deberes ${ }^{64}$. Protagonista del nacimiento del marxismo italiano y muy cercano a Engels y a Sorel, con los cuales estableció una

\footnotetext{
${ }^{59}$ París, La Formación ideológica de José Carlos Mariátegui, pp. 128-130.

${ }^{60}$ En particular París subraya señala el parentesco entre una página de los Sietes Ensayos y la interpretación del filósofo italiano sobre el problema de los caudillos en la política. Como Labriola señaló "estos hombres", o sea los caudillos, no son: "Ni un accidente despreciable del mecanismo social, ni creadores maravillosos de lo que sin ellos la sociedad no habría hecho en modo alguno. Es la trama misma de las condiciones antitéticas lo que hace que ciertos individuos, geniales, heroicos, afortunados o malos, son llamados en los momentos críticos a decir la palabra decisiva. Esta interpretación, señala París, es muy parecida a cuanto escrito de Mariátegui cerca el rol de los caudillos en la creación de un nuevo orden jurídico y económico, que no puede ser en todo caso, la obra de un caudillo sino de una clase. Cuando la clase existe, el caudillo funciona como su intérprete y su fiduciario. No es ya su árbitro personal, sino un conjunto de intereses y necesidades colectivas lo que decide su política". Véase París, La formación ideológica de José Carlos Mariátegui, pp. 140-141.

${ }^{61}$ SiCILIANI DE CUMIS, "Per una 'Autobiografia' intellettuale e política di Antonio Labriola", en Studi Storici, Anno 26, oct-dic 1985, pp. 778.

${ }^{62}$ A pesar de las diferencias entre los dos autores, en este apartado mi análisis tratará demostrar como las características del pensamiento marxista que acomunaron Croce y Labriola fueron las retomadas por Mariátegui. Para un análisis sobre las divergencias entre los dos filósofos, véase COLBERT JR., "Labriola, Croce, Anti-Croce", en Studies in Soviet Thought, vol. 24, No. 2 (Aug., 1982), pp. 147-160.

${ }^{63}$ Ésta fue la caracterización del marxismo italiano ofrecida por Labriola en 1899, durante un Congreso de los Sindicatos de Trabajadores de Roma, cit. en SICILIANI DE CuMIS, "Per una "Autobiografia" intellettuale e política di Antonio Labriola”, en Studi Storici, Anno 26, oct-dic 1985, pp. 778.

64 Véase SiCILIANI DE CUMIS, "Per una "Autobiografia” intellettuale e política di Antonio Labriola", en Studi Storici, Anno 26, oct-dic 1985, pp. 778.
} 
intensa correspondencia epistolar, Labriola trató cuestionar la visión de socialismo que reinaba en los países latinos, en particular Italia. La idea de que "Italia no es madura para el socialismo, sobre todo a causa de la falsificación del verdadero socialismo por un lado y del anarquismo por el otro" lo llevó a una dura crítica hacia el ideal de socialismo en la península:

En los países latinos ha ocurrido un hecho muy extraño. La doctrina del socialismo contemporáneo penetra, no por la directa difusión de los principios y de las enseñanzas de los maestros del socialismo contemporáneo, sino por las divulgaciones que han hecho los comentadores, propagandistas o críticos académicos, todos más o menos interesados en exagerar, en falsear ó en atenuar algunos lados de la doctrina ${ }^{65}$.

A través de esta actitud crítica, y convencido de volver a los clásicos de la teoría marxista, Labriola trató poner en tela de juicio el demasiado énfasis puesto por algunos autores marxistas hacia la economía, subrayando la importancia del elemento histórico. Según Labriola, la actitud economicista que reinaba en Alemania se podía explicar solamente por "el amor a la paradoja, inseparable siempre del celo de los apasionados divulgadores de una doctrina nueva" que indujo varios pensadores a "la creencia de que para escribir la historia basta poner en evidencia tan solo el momento económico [...], arrojando todo el resto como inútil fardo, con que los hombres se cargaron a voluntad como accesorio o simple bagatela" 66 .

Las mismas preocupaciones eran compartidas también por Benedetto Croce. El filósofo originario de Nápoles, que retomó y profundizó el análisis hecha por Labriola, demostró siempre un cierto malhumor hacia los economistas puros, "los cuales traducen en conceptualismo psicológico la razón del riesgo y otras análogas consideraciones de la obvia práctica comercial"67. Para Croce desde el punto de vista económico, el marxismo no podía ser definido como ciencia económica general, sino que la justificación de la "ciencia económica marxista", descansaba en ser una "economía sociológica comparativa, que trata de las condiciones del trabajo en las sociedades capitalistas" $" 68$.

Empezando por esta crítica al súper estructuralismo económico, tanto Labriola como Croce retomaron la importancia de la complejidad histórica, llamando la atención sobre cómo, en la doctrina socialista, el aspecto más importante no era el de "traducir nuevamente en categorías económicas todas las complicadas manifestaciones de la historia" sino "de explicar en última instancia (Engels) cualquier hecho histórico por medio de la estructura económica que está debajo (Marx)"69. Esto, según Labriola, implicaba "análisis y reducción, y después mediación y composición" más la necesidad de utilizar, en la comprensión de la historia, la que podemos llamar "psicología social"70.

\footnotetext{
${ }^{65}$ LABRIOLA, "El ideal de socialismo", en Reforma y revolución social, p. 187.

${ }^{66}$ LABRIOLA, Del materialismo histórico, p.22.

${ }^{67}$ CROCE, Conversazioni critiche, 1950, p.290.

${ }^{68}$ CROCE, Materialismo histórico y economía marxista, p. 139.

${ }^{69}$ Colbert JR., "Labriola, Croce, Anti-Croce”, en Studies in Soviet Thought, vol. 24, No. 2 (Aug. 1982), pp. 147-160.

${ }^{70}$ CROCE, Materialismo histórico y economía marxista, pp. 22-25.
} 
La nueva interpretación de Labriola, que describía el marxismo como un nuevo weltanschauung, o sea una nueva concepción general de la vida y del mundo, capaz de irse más allá del determinismo económico, abrió la posibilidad de una nueva interpretación marxista, interpretación más abierta, no concebida como una suerte de biblia ${ }^{71}$. Asimismo, el marxismo de Mariátegui no radicaba en una rígida estructura dogmática. Para el peruano, el marxismo no era un método "de interpretación de la realidad cuyo principio fundamental es el condicionamiento de la superestructura por la infraestructura económica", sino que "la acción" era más importante "de la interpretación" "72. Mariátegui rechazaba, como los dos pensadores italianos, la ortodoxia marxista, es decir entender el marxismo como una fijación de reglas, una lectura escolástica, una formulación simplificada y simplista de un nuevo pensamiento. Por esto optó por un método de análisis que, como Labriola repitió en más de una ocasión, tenía que empezar por "las peculiaridades del vivir humano" y privilegiar la "vocación practica a la teórica"73. El mismo Croce, retomado por Mariátegui, miraba a Marx no principalmente como un filósofo, sino como un hombre práctico, "un revolucionario, un agitador, un consejero político del movimiento proletario"74, y especificó cómo su obra no debía ser considerada como un catequismo, sino como una orientación.

Fue con este esquema teórico que Mariátegui, en la serie de artículos que componen la obra Defensa del Marxismo, se opuso a la obra de Henry de Mann ${ }^{75}$. El director de Amauta había utilizado el pensamiento de Croce y Labriola, para sustentar cómo "el presupuesto del socialismo no es de buscar en una filosofía de la historia", sino "en la concepción histórica determinada por las condiciones presentes en la sociedad"; y después decretó la "bancarrota del positivismo y del cientificismo que, como filosofías, no comprometen el marxismo" ". Mariátegui siguió condenando "el darwinismo social y político", reo de haber "invalidado, como una epidemia [...] las mentes de vario investigadores, y algo más de los abogados y declamadores de la sociología, ha venido a reflejarse, como un vestido de moda y como una corriente fraseológica, hasta el lenguaje diario de los politicastros" 77 . Tomando como base este análisis Mariátegui atacó también la clase burguesa, que con sus "historicismo y evolucionismo dogmático" antes habían rechazado, en nombre del racionalismo, cualquier "utopismo igualitario", mientras que ahora "se reconciliaban con "todas las iglesias y las supersticiones" para "resistir a la avanzada del socialismo" "78.

\footnotetext{
${ }^{71}$ Según Labriola el marxismo "no se encuentra y no se encontrará encerrado totalmente en los escritos de Marx y Engels [...] en el marxismo no hay catecismo que puedan valer”. Véase LABRIOLA, Del materialismo histórico, p.35.

72 ILlÁn MeSEGUER, José Carlos Mariátegui y su pensamiento revolucionario, p. 138.

${ }^{73}$ ZANGHERI, "Il marxismo di Antonio Labriola. Un riesame", en Studi Storici, Anno 44, No. 1 (Jan. -mar., 2003), p. 157.

${ }^{74}$ CROCE, Materialismo histórico y economía marxista, p. 120.

${ }^{75}$ En Defensa del marxismo Mariátegui refutó la propuesta teórica del texto de Henri de Man, Más allá del marxismo. Según el peruano, que rechazó el positivismo de la obra escrita por de Man, "El marxismo donde se ha mostrado revolucionario-vale decir donde ha sido marxismo-no ha obedecido nunca a un determinismo pasivo y rígido". Véase MARIÁTEGUI, Defensa del Marxismo, p. 11.

${ }^{76}$ MARIÁTEGUI, "La filosofía moderna y el marxismo", en Defensa del Marxismo, p.40.

${ }^{77}$ Ibid., p.43.

${ }^{78}$ MARIÁteGUi, "El idealismo materialista”, en Defensa del marxismo, p.88
} 
Otra relación interesante entre el pensamiento de Mariátegui y el de Labriola se puede apreciar en la importancia que los dos autores asignaron al nivel ético en la política y a la función de la educación en la clase obrera. Labriola siempre rechazó una manera de hacer política que era por cierto real y realista, pero corrupta, degenerada, degradada ${ }^{79}$. Ya en 1886 participó en la vida política italiana, no con un programa de matriz socialista marxista, sino de signo liberal-progresista, donde enfatizaba la importancia del nivel éticopedagógico en la política. La importancia de esta visión ética se transfirió, después del contacto con el movimiento obrero, en la formación del naciente movimiento socialista italiano. Según Labriola, quien no se cansaba de criticar los aspectos de corrupción moral e intelectual de muchos "politicastros", eran "las pasiones que hacen la historia" 80 . El concepto de socialismo no se puede implantar en la cabeza de los trabajadores con tan sólo un orden del día, sino que era una cuestión de experiencia, táctica, educación e instrucción y, entonces, de tiempo"81. La construcción de un movimiento revolucionario necesitaba de una nueva ética, la "ética del socialismo", o sea el postulado "de la solidaridad contrapuesto al axioma de la competencia" 82 . Labriola, en este sentido, siempre subrayó la importancia del socialismo alemán y el papel de la pedagogía social: "un número tan grande de obreros y de pequeños burgueses forman una conciencia nueva, a la cual concurren en igual medida el sentimiento director de la situación económica, que induce a la lucha, y la propaganda del socialismo, entendido como meta y punto de arribo" "83. En sus estudios sobre los orígenes de la clase obrera, Labriola desarrolló también una especial simpatía por las creencias religiosas, que el catalogó como "mitos", describiendo el socialismo como "la filosofía del futuro y una nueva religión para la humanidad"84.

El mismo Mariátegui citó a Labriola en su análisis sobre "ética y socialismo", destacando la importancia del socialismo alemán como caso verdaderamente nuevo e impotente de pedagogía social ${ }^{85}$. Hablando de la relación entre ética y socialismo, el intelectual peruano reivindicó la necesidad de que el marxismo se planteara una "cuestión moral", con el fin de buscar una "función ética del socialismo" "86. Ésta debía llevar a la creación de una nueva moral entre los trabajadores, una moral que Mariátegui definió como "moral de productores", posible solamente gracias a un largo aprendizaje y a una notable

${ }^{79}$ GerratanA, “Antonio Labriola e la política”, en Studi Storici, Anno 1926, No. 3 (jul.- sept., 1985), pp. 565-580.

${ }^{80}$ LABRIOLA, Saggi sul materialismo storico, p. 320.

${ }^{81}$ LABriola, Epistolario 1890-1895, cit. en GerRatanA, Antonio Labriola e la política, en Studi Storici, Anno 1926, No. 3 (jul.- sept., 1985), pp. 570.

${ }^{82}$ LABRIOLA, Saggi sul materialismo storico, p. 350.

${ }^{83}$ Véase LABRIOLA, "Carta de Labriola a Sorel", Roma, 24 de abril de 1897, en Reforma y revolución social, p. 143.

84 Véase Colbert JR., "Labriola, Croce, Anti-Croce”, en Studies in Soviet Thought, vol. 24, No. 2 (Aug. 1982), pp. 153.

85 "Ética y Socialismo", en Defensa del marxismo, p.53. Según Robert París esta cita sobre Labriola fue tomada por Mariátegui del Materialismo Storico de Croce, donde el filósofo napolitano señaló que “ Labriola tiene razón de admirar, en el crecimiento del socialismo alemán «ese caso verdaderamente nuevo e imponente de pedagogía social; o sea que en un número tan grande de hombre, y particularmente de obreros y de pequeños burgueses se forme una conciencia nueva, a la cual concurren en igual medida el sentimiento de la situación económica, que induce a la lucha, y la propaganda del socialismo, entendido como mete a punto de arribo”. Véase PARÍs, La formación ideológica de José Carlos Mariátegui, p. 125.

${ }^{86}$ MARIÁtEGUI, "Ética y socialismo”, en Defensa del Marxismo, p. 49. 
acción educativa por parte de los dirigentes socialistas ${ }^{87}$. En sus reflexiones sobre el sindicalismo, el mismo Mariátegui, al igual que Labriola, propuso tomar en cuenta "la función pedagógica y espiritual del sindicato y de la fábrica", subrayando, como "si el socialismo no debiera realizarse como orden social, bastaría esta obra fundamental de educación y elevación para justificarlo en la historia" 88 .

\section{Mariátegui y Gramsci: más allá de la cercanía intelectual y de espíritu}

Las relaciones intelectuales entre Mariátegui y Antonio Gramsci no han recibido, hasta ahora ningún estudio específico. Autores como Robert París y Antonio Melis han subrayado la "cercanía intelectual y de espíritu", las profundas "semejanzas" y las "coincidencias" biográficas e ideológicas entre los dos autores, excluyendo cualquier influencia directa del pensamiento gramsciano en la obra de Mariátegui ${ }^{89}$. Aunque Mariátegui nunca citó explícitamente las obras de Gramsci en sus memorias sobre Italia o en sus escritos posteriores, pensamos que un estudio detallado entre los dos intelectuales revela semejanzas interesantes.

Antes de proceder con el análisis es necesario precisar algunos puntos que tienen que ver con la bibliografía y el contexto social en el cual los dos autores crecieron. Ellos, a nivel personal, fueron probablemente unidos por la misma pobreza del hogar, la semejante dolencia física, las difíciles relaciones con los ambientes universitarios y la pasión por el periodismo (Gramsci dirigió ya en 1917 El Grito del Pueblo, primer semanal de la sección socialista turinés). Más allá de las semejanzas biográficas creo necesario subrayar las peculiaridades del desarrollo de su pensamiento. Ya hemos podido apreciar la formación heterogénea y "poco ortodoxa" de Mariátegui. La formación intelectual del mismo Gramsci tuvo peculiaridades que debemos tener en cuenta. Como otros autores del Ordine Nuovo, el mismo Gramsci vivió la querella intelectual anti-positivista que caracterizó la Italia de inicio siglo, donde la distancia, también generacional, que separaba los viejos positivistas con una conciencia organicista y naturalista de la sociedad y la defensa de prácticas políticas y estatistas- de los nuevos idealistas -que concebían la emancipación política como un proyecto humano, obra de la voluntad de individuos asociados- era enorme. Gramsci tomó partido por esta segunda corriente ${ }^{90}$. Aunque su formación juvenil se nutrió de liberalismo la herencia de Croce $^{91}$, el eco de las batallas liberales radicales de Gaetano Salvemini, la atracción hacia un esquema anarcosindicalista con claro contenido antireformista, nacido del rechazo del "socialismo no socialista" alemán subalterno al

\footnotetext{
${ }^{87}$ Ibid., p. 51.

${ }^{88}$ MARIÁTEGUI, "Ética y socialismo”, en Defensa del Marxismo, pp. 53.

${ }^{89}$ Véase PARís, La formación ideológica de José Carlos Mariátegui, pp. 85-92 y MELIS "El debate sobre Mariátegui: Resultados y problemas”, en Revista de Crítica Literaria Latinoamericana, Año 2, No. 4, 1976, p. 130.

90 Famosa es su aclaración de Gramsci de "la teoría de la evolución como doctrina de la inercia". Véase GRAMSCI, Escritos políticos (1917-1933), p. 327.

${ }^{91}$ Según Palmiro Togliatti la influencia de Croce: "Para nosotros del Ordine Nuovo el cambio cultural hecho por el idealismo crociano significó, antes de todo, la liberación definitiva de cualquier incrustación positivista y mecanicista y la conquista de una gran fe en el desarrollo de la conciencia y de la voluntad de los hombres y de nosotros mismos, como parte de un gran movimiento histórico renovador de clase". Véase TOGLIATTI, Il Partito Comunista Italiano, p. 34
} 
capitalismo y el proteccionismo del estado prusiano, caracterizó la formación del joven Gramsci $^{92}$.

Lo que quiero destacar, importante para entender la cercanía entre el intelectual de Cerdeña y Mariátegui, es que el joven Gramsci, a diferencia del Gramsci de los "Cuadernos del Cárcel", estaba interesado al estudio del Marx "genio político", promotor de una conciencia revolucionaria y de una acción revolucionaria a favor de los oprimidos, y del Sorel de las reflexiones de las violencias, que exaltó la espontaneidad de las luchas obreras y el mito de la "huelga general". En pocas palabras, los mismos aspectos de la reflexión de los dos autores que siempre fascinaron a Mariátegui ${ }^{93}$. Aunque el octubre rojo y el bolchevismo matizaron estas tendencias idealísticas, en 1922-1923, cuando Mariátegui se relacionó con la cúpula del Ordine Nuovo, Gramsci defendía una mirada del marxismo que era la misma que Mariátegui estaba asimilando gracias a las lecturas de los textos de Croce y Labriola: un marxismo que ponía énfasis sobre el papel principal de la subjetividad en los procesos revolucionarios, sobre la importancia de reconocer el lugar de la voluntad y de la conciencia en la historia de la sociedad y el rescate de elementos irracionales, como tradición, cultura esperanza y utopía en el desarrollo humano ${ }^{94}$.

Estas características pueden ayudarnos a entender la cercanía entre el autor peruano y el italiano. Hay otro punto importante que arroja luz sobre las relaciones entre los dos intelectuales: la amistad y la colaboración entre Gramsci y Gobetti en los años 1922- 1923. Como es sabido, el referente privilegiado de Mariátegui en su estancia en Italia fue el liberal turinés, que en 1922 fue llamado por el mismo Gramsci a colaborar con el Ordine Nuovo $^{95}$. Aunque no existen pruebas ciertas de las relaciones directas entre Mariátegui y Gramsci todos los indicios nos llevan a esta conclusión. La suposición es reforzada por la primera de las similitudes entre los dos autores: la que tiene que ver con la interpretación del fenómeno fascista. Fue en particular el rol de la pequeña burguesía, de la violencia y de la composición de clase del movimiento fascista a atraer la atención de los dos intelectuales. Según Gramsci era la pequeña burguesía que, "como esclava del capital”,

\footnotetext{
92 Para un análisis detallado de los primeros años de Gramsci en Turín Véase SPRIANO, “Gramsci e Gobetti”, en Studi Storici, Anno 17, No.2 (Aprile- Giugno 1976), pp. 69-93.

${ }^{93} \mathrm{El}$ acento voluntarista fue muy marcado también en Mariátegui. Por ejemplo, en su artículo publicado en El alma matinal donde Mariátegui retoma el ejemplo de José Vasconcelos hablando de "Pesimismo de la realidad y optimismo del Ideal": "los que no nos contentamos con la mediocridad, los que menos aún nos conformamos con la injusticia, somos frecuentemente designados como pesimistas. [...] no creemos que el mundo debe ser fatal y eternamente como es. Creemos que puede y debe ser mejor. El optimismo que rechazamos es el fácil y perezoso optimismo panglosiano de los que piensan que vivimos el mejor de los mundos posibles". Véase MARIÁTEGUI, El alma matinal, p. 28.

${ }^{94}$ En este sentido es indicativo, para entender el Gramsci de estos años recordar las peleas entre Gramsci, que defendía la revolución de octubre como "milagro de la voluntad" y el determinismo del primer secretario del partido Comunista Italiano, Amedeo Bordiga, que sostenía la idea de creer en la revolución "no como el católico cree en Cristo, sino como el matemático cree en los resultados de su investigación”. SPRIANO, “Gramsci e Gobetti", en Studi Storici, Anno 17, No. 2 (Aprile- Giugno 1976), p. 74.

95 Gramsci y Gobetti ya se encontraron en 1919, después de un invito que Gramsci aceptó por escribir un artículo en la revista universitaria dirigida por Gobetti. La consonancia psicológica e intelectual entre los dos intelectuales italianos fue muy fuerte. A demostración de esta quizás sea necesario recordar como El famoso "odio a los indiferentes" de Gramsci y el "Odio a la Apatía" de Gobetti, que no son declaraciones abstractas, sino parte de la personalidad de los dos. Véase SPRIANO, “Gramsci e Gobetti”, en Studi Storici, Anno 17, No. 2 (Aprile-Giugno 1976), pp. 69-93
} 
representó el motor del movimiento fascista, que se había unido al capitalismo financiero para realizar la contra-revolución italiana. Aunque el fascismo había nacido en un centro industrial como Milán, comenzó, según Gramsci, a reclutar el grueso de sus fuerzas entre los pequeños y grandes terratenientes, que esperaban la ocasión propicia para luchar contra las organizaciones obreras y socialistas. "La pequeña burguesía, especialmente la rural, da al fascismo sus efectivos; ella se encuentra militarmente delante del proletariado y contra el proletariado"96.

También Mariátegui reconoció la importancia de la pequeña burguesía descontenta, fenómeno que nació en las ciudades y se extendió rápidamente al campo, creando una similitud entre fenómenos como el nacionalismo alemán y el fascismo italiano, que "se abastecen de los hombres de la provincia, en la campaña"97. La violencia fascista, que Mariátegui vio con sus ojos de 1920 hasta 1922, fue interpretada por el peruano como una consecuencia de la Primera Guerra Mundial, que tuvo entre los otros resultados, un "culto de la violencia" enfatizado por la anima "guerrera y mística" insuflada en la doctrina socialista por la revolución rusa" así que la burguesía, para defenderse del peligro rojo, tuvo que "apelarse a la violencia fascista" juveniles, consideró el fascismo como un movimiento contra-revolucionario dirigido por "la violencia capitalista", posible de frenar solamente con la insurrección armada del pueblo ${ }^{99}$.

Mariátegui también comparte con Gramsci algunas reflexiones sobre el concepto autónomo de socialismo y la caracterización de la vanguardia revolucionaria. El debate de Gramsci sobre la "autosuficiencia del marxismo" tuvo una doble vertiente: filosófica y práctica. Este tema, herencia del marxismo de Labriola y Croce, fue desarrollado inicialmente por Gramsci en sus escritos juveniles y tratado con más detalle en los cuadernos de la cárcel. Según Labriola la palabra "autonomía" significaba reconocer el marxismo como una teoría científica de la sociedad que tenía su objeto particular de análisis. O sea, el marxismo, siendo filosofía científica de la sociedad y de la historia tenía sus propias teorías que no podían ser confundidas con las de las ciencias naturales ${ }^{100}$. Gramsci se fue más allá del énfasis prevalentemente metodológico que tenía la visión del marxismo en Labriola, defendiendo el marxismo no solamente como método, sino también como "filosofía, integral y general de la concepción de la realidad", una nueva "visión del mundo", como Gramsci sostuvo ya en $1922^{101}$.

El mismo Mariátegui, en el texto Defensa del Marxismo, trató de manera tangencial este debate, quedándose en un análisis filosófico superficial, pero tratando de darle un contenido práctico, que se tradujo en la construcción de una fuerza socialista autónoma, liberada de alianzas de tipo populistas con la pequeña burguesía. Como ya mencioné,

\footnotetext{
${ }^{96}$ GRAMSCI, La Questione meridionale, p. 64.

97 “La teoría fascista”, MARIÁTEGUI, La escena contemporánea, pp. 28 - 34.

98 "Los nuevos aspectos de la batalla fascista”, MARIÁTEGUI, La escena contemporánea, pp. 28 - 34.

99 "La conquista fascista del Estado", en GRAMSCI, Escritos Políticos (1917-1933), p. 215.

${ }^{100}$ Según Labriola, "el marxismo [...] es una de las maneras en la cual el espíritu científico se ha liberado de la filosofía en sí misma”. Véase Labriola, La concezione materialista della storia, p. 67.

101 Sobre la problemática, véase CONIGLIONE "Gramsci e il pensiero marxista tra storicismo e scienza", en SAlMIERI y PIGNATO, Gramsci e la formazione dell'uomo. Itinerari educativi per una cultura progressista, pp. 81-113.
} 
Mariátegui no aportó mucho al debate filosófico sobre la autonomía del marxismo, ya que se limitó a remarcar la necesidad de liberarse de la herencia positivista ("El marxismo donde se ha mostrado revolucionario no ha obedecido nunca a un determinismo pasivo y rígido" ${ }^{102}$ ) y subrayando, como hizo Labriola, que el rechazo del positivismo no significaba un rechazo del mundo de la ciencia, sino que el abandono de la idea que sea posible explicar todos los fenómenos a través de una ley única ${ }^{103}$. Dejando de lado la vertiente filosófica del debate alrededor de la autonomía marxista, donde Mariátegui demostró otra vez su adhesión a las teorías de Labriola, la similitud con Gramsci se puede apreciar en las consecuencias prácticas de la cuestión de la autonomía.

El intelectual sardo, durante el III Congreso del Partido Comunista de Italia en 1926, planteó el problema del peligro, en el caso italiano, de la construcción de un partido comunista edificado sobre la síntesis de "elementos heterogéneos", es decir, abrir el movimiento obrero a la "influencia paralizadora de otras clases diferentes de la proletaria $^{104}$. El análisis de Gramsci tenía como referencia la situación italiana, donde el débil desarrollo capitalista no permitía de absorber toda la población en el sector industrial $^{105}$. Rechazar los elementos heterogéneos no significaba, según Gramsci, que el partido tenía que ser solamente un partido de obreros. El rol de los intelectuales debía ser importante, así como el de los campesinos, necesarios para fortalecer los lazos políticos entre proletariado y la clase rural; pero la dirección del partido "tenía que estar en las manos del proletariado y excluir las clases medias"106. Esta lectura fue hija de un cambio en la visión del intelectual sardo sobre la composición de la vanguardia revolucionaria: si en 1919-1920 Gramsci planteó la necesidad de una unión entre obreros y campesinos, ya en 1922 a través de las columnas de Ordine Nuovo, manifestó la tendencia a sobrevalorar el rol único del proletariado industrial ${ }^{107}$.

Es curioso cómo el mismo Mariátegui, en algunos textos escritos después de su viaje a Europa, compartió con Gramsci el origen ciudadano de la vanguardia revolucionaria y la función de las clases medias en la construcción del partido socialista. Según Mariátegui, el espíritu revolucionario "siempre reside en las ciudades, porque es aquí donde el capitalismo ha llegado a su plenitud y donde se libra la batalla entre el orden individualista y la idea socialista"108. El intelectual peruano, convencido de que "la mentalidad del campesino tiende naturalmente a la "adquisición de una pequeña propiedad

\footnotetext{
102 MARIÁTEGUI, Defensa del marxismo, p. 11

103 Por ejemplo, la "ley de la evolución”. Véase Mariátegui, Defensa del marxismo, p. 23.

104 Véase Antonio Gramsci, Tesi del II Congresso del Partito Comunista d'Italia, Lione, Gennaio 1926, en www.antoniogramsci. org.

${ }^{105}$ Según Gramsci la población activa de Italia estaba constituida por cuatro millones de obreros industriales, tres millones y medio de obreros agrarios y cuatro millones de campesinos. Véase Antonio Gramsci, Tesi del II Congresso del Partito Comunista d'Italia, Lione, Gennaio 1926, en www.antoniogramsci.org.

106 Antonio Gramsci, Tesi del II Congresso del Partito Comunista d'Italia, Lione, Gennaio 1926, en www.antoniogramsci.org.

107 “En Italia será la clase obrera la que se colocará a la vanguardia de la revolución, porque, entre las víctimas de la propiedad privada, sólo el proletariado tiene una doctrina política, el marxismo" "El poder en Italia", en GRAMSCI Escritos políticos (1917-1933), p. 35.

${ }^{108}$ MARIÁTEGUI, El alma matinal, p. 37.
} 
individual", defendió la tarea de la ciudad como "educadora al colectivismo"109. ¿Cómo analizaba Mariátegui la formación del movimiento socialista? Según Mariátegui el partido debía surgir al interior del movimiento social como una expresión política genuina de los obreros y campesinos organizados y, como bien señala Aricó, el partido debía materializarse como el resultado de la lucha social donde el proletariado tenía que jugar un papel protagónico, aglutinando a las grandes mayorías nacionales ${ }^{110}$.

Antes de terminar este apartado, me parece necesario subrayar otra similitud entre los dos pensadores: la relacionada a la cuestión meridional de Gramsci y la caracterización de la situación peruana desarrollado por Mariátegui en los Siete Ensayos. Aunque la idea acerca del proceso inconcluso de construcción nacional será analizada en el siguiente apartado sobre Gobetti, es necesario señalar algunos parentescos entre la idea de "catarsis gramsciana" y el carácter dual de la sociedad peruana. Gramsci, hombre del sur, ya cercano al autonomismo sardo en 1913, conocía bien las problemáticas meridionales, un meridión "pobre y analfabeta, afuera del al estado italiano""111, y siempre trató de lograr una incorporación del sur al estado nacional. El problema principal del sur era, según Gramsci, lo de la territorialidad ${ }^{112}$, que tenía como consecuencia la creación de "dos Italias": un sur "inmenso campo" y un norte "inmensa ciudad"113. Este dualismo campo/ciudad, que se traducía según Gramsci en un dualismo entre feudalismo/modernidad, era herencia del proceso de construcción nacional italiana. La nueva Italia nacida con la independencia "había encontrado en situación totalmente antitéticas las dos partes de la península, meridional y septentrional, que se juntaban después de más de 100 años" ${ }^{114}$. Por un lado, tradición de autonomía y burguesía audaz y llena de iniciativas del norte; por la otra el sur, donde las administraciones españolas y borbónicas no habían creado nada:

La burguesía no existía, la agricultura era primitiva y no podía satisfacer el mercado local [...]. La grande propiedad terrera se ha quedado afuera de la libre concurrencia: el estado moderno ha respectado su esencia feudal [...] y la mentalidad del campesino sigue siendo la del servo de la gleba, que se rebela de manera violenta en contra de los señores, pero es incapaz de pensar a sí mismo como el miembro de una colectividad y de desarrollar una acción sistémica y

\footnotetext{
${ }^{109}$ Mariátegui llegó a sostener que "la última batalla entre el individualismo y el socialismo se librará, tal vez, entre ciudad y campo”, Véase MARIÁTEGUI, La escena contemporánea, p. 173.

110 ARICÓ, "Mariátegui y la formación del partido socialista en Perú", en Socialismo y Participación No. 11. El mismo Mariátegui, en el programa del partido socialista peruano, sostuvo la necesidad de construir el partido sobre la vanguardia del proletariado, "fuerza política que asume la tarea de su orientación y dirección en la lucha realizada por los ideales de clase". Véase MARIÁTEGUI, "Programa del Partido socialista peruano", 1928.

${ }^{111}$ GRAMSCI, "Il mezzogiorno e la guerra", en Scritti Giovanili, p. 67.

112 Según Gramsci el problema de la territorialidad era entender de la misma manera que lo de "los pueblos sujetos a dominación imperialista, donde el imperialismo es una actitud típica del funcionamiento del sistema capitalista". Véase URbinAti, "Le passioni e la política. Il meridione di Antonio Gramsci”, en Studi Storici, Anno 37, No. 2, Il tempo di Federico II (Aprile-Giugno 1996), pp. 465-487.

113 GRAMSCI, La cuestione meridionale, p. 34.

114, "Il Mezzogiorno e la guerra", por Antonio Gramsci en "Il Grido del popolo", 1 de abril de 1916, en GRAMSCI, La Questione meridionale”, p. 55.
} 
permanente que tenga como fin cambiar las relaciones económicas y políticas de la convivencia social ${ }^{115}$.

Una clase campesina que, según Gramsci, siempre había vivido "fuera del dominio de la ley, sin personalidad jurídica, sin individualidad moral: se quedó como elemento anarco, el átomo independiente de un túmulo caótico, controlado solamente por el miedo del carabinero o del diablo"116. ¿Qué solución propuso Gramsci, en sus escritos juveniles, para resolver esta situación? El intelectual sardo creó la idea de la "catarsis", o sea la elevación del momento puramente egoistico y pasional (económico) al momento ético-ideal (político) ${ }^{117}$. En otras palabras, un marxismo idealista fue la manera avanzada por Gramsci de resolver la cuestión meridional.

Mariátegui, en los Sietes Ensayos, presentó la misma visión de Perú como una sociedad de carácter dual, con un dualismo que, como subraya Silvia Funes, se podía notar en varias dicotomías, como la económica entre costa/sierra, la racial entre blanco/indios y la social política entre feudalismo/ modernidad ${ }^{118}$. Según Mariátegui:

En el Perú actual coexisten elementos de tres economías diferentes. Bajo el régimen de la economía feudal nacido de la Conquista subsisten en la sierra algunos residuos vivos todavía de la economía comunista indígena. En la costa, sobre un suelo feudal, crece una economía burguesa que, por lo menos en el desarrollo mental, da la impresión de una economía retardada ${ }^{119}$.

El mismo dualismo entre feudalismo y modernidad tuvo, también por Mariátegui, la consecuencia de una exclusión del indio de la vida nacional; indio considerado como hombre que tenía una actitud "envilecida y deprimida [...] incapaz de toda lucha en contra de sus explotadores"120. ¿Dónde encontró Mariátegui la posibilidad de resolver este dilema? La única manera para lograr una unidad nacional y una transformación social descansaba, según el peruano, en una ilusión, un mito, que si se encarnaba en los hombres podía convertirse en el motor de la historia.

\section{Gobetti y Mariátegui: el difícil proceso de construcción de la Nación}

La persona con quien, tanto a nivel personal como intelectual, Mariátegui se sintió más en sintonía, fue Piero Gobetti. Como en el caso de Gramsci, precedentes bibliográficos y, sobre todo en el caso de Gobetti, unos comunes desarrollos intelectuales crearon esta afinidad de espíritu. Testimonio de esta cercanía y relación de estima es el primero de los tres artículos que Mariátegui escribió sobre Gobetti que fueron publicados por El Mundial en 1929, donde el director de Amauta criticó la superficialidad que en Perú se ha hecho de la "asimilación de la mejor Italia, la irregularidad de nuestro trato con su más sustanciosa

\footnotetext{
115 “Operai e Contadini”, “L'ordine Nuovo”, 2 de agosto de 1919, en GRAMSCI, Scritti Giovanili, p. 34.

116 GRAMSCI, La cuestione meridionale, p. 45.

117 GRAMSCI, La cuestione meridionale, p. 47.

${ }^{118}$ FUNES, Salvar la nación. Intelectuales, cultura y política en los años vente latinoamericanos p. 130.

${ }^{119}$ MARIÁTEGUI, Siete Ensayos, p. 32.

${ }^{120}$ MARIÁtegui, Ideología y política, p. 80.
} 
cultura". Señalando las lagunas de la transmisión española de las corrientes intelectuales y artísticas de Italia, que ha sido "irregular, insegura y defectuosa", Mariátegui puso en claro cómo esto tuvo en consecuencia un estudio insuficiente de Croce y, sobre todo, el "completo desconocimiento de Piero Gobetti" ${ }^{21}$.

Mariátegui subrayó que en la obra de Gobetti se podía apreciar "una originalidad de pensamiento, una fuerza de expresión, una riqueza de ideas que están muy lejos de alcanzar los escritores de la misma generación a quienes la política gratifica con una fácil reputación internacional" ${ }^{122}$. Por estos motivos, y por el "sentimiento de justicia, una acendrada simpatía por el hombre, un leal propósito de contribuir al conocimiento de los más puros y altos valores de la cultura italiana" ${ }^{223}$, el estudio y el conocimiento de Gobetti debían extenderse a Perú y América Latina.

¿Quién era este hombre que tanta admiración despertó en Mariátegui? Gobetti nació en 1901, hijo de una familia campesina de Turín. Estudiante brillante, empezó la universidad en 1918 y prontamente fundó un periódico, Energie Nove, conducido por Francesco Ruffini, su profesor de jurisprudencia de orientación liberal y con la colaboración de Luigi Einaudi, economista de matriz liberal que dedicaba una gran atención a los problemas de la naciente clase obrera turinés. En 1919 Gobetti invitó a dos de los más importantes intelectuales socialistas italianos de la época, Antonio Gramsci y Angelo Tasca, quienes escribieron cuatro artículos de diciembre de 1918 a junio de $1919^{124}$. Esta temprana experiencia como periodista fue una etapa fundamental para Gobetti; Energie Nove, más que un simple periódico, era uno de los lugares de reflexión de la intelligentzia de Turín, donde se trataban temas de literatura, filosofía, política y economía. Liberal atípico, Gobetti fue atraído también por los estudios históricos, por lo que investigó sobre los orígenes del liberalismo en Piamonte en el siglo XVIII y por la filosofía, acercándose al idealismo gentiliano antes de su viraje hacia el fascismo y, como todos los intelectuales de la época, por historicismo de Croce.

A pesar de su liberalismo inicial, el pensamiento de Gobetti fue ecléctico. Después del bienio rojo y de las experiencias de la ocupación de la fábrica por parte de los obreros del Alfa Romeo, Gobetti quedó impresionado por el movimiento de protesta y la actitud de los obreros, y sostuvo:" Hoy la revolución está tomando por entero un carácter religioso [...] una pequeña minoría está para imponer toda su fuerza de sacrifico. Las masas siguen una vocación heroica, como siempre. El movimiento es espontáneo y completamente libre de fines materiales ${ }^{125}$. La situación de Turín de los años veinte cambió y profundizó el análisis de Gobetti. Con las ocupaciones de las fábricas su interés pasó del liberalismo a otros temas de relevancia: el sacrificio, la dominación del poder y de la fuerza para lograr

\footnotetext{
121 Véase: "Piero Gobetti" (12 de julio de 1929), "La Economía y Piero Gobetti” (26 de julio de 1929) y Piero Gobetti y el Risorgimento (15 de agosto de 1929), en MARIÁTEGUI, El alma matinal, pp. 110-121.

122 Ibid., p. 113.

123 Ibid., p. 111.

124 VANEK, "Piero Gobetti and the Crisis of the Primo Dopoguerra", The Journal of modern History, Vol. 37, No. 1 (Mar. 1965), p. 15.

125 VANEK, "Piero Gobetti and the Crisis of the Primo Dopoguerra", The Journal of modern History, Vol. 37, No. 1 (Mar. 1965), p. 6.
} 
los objetivos, la obra de una "minoría heroica que luchaba con determinación religiosa" fueron al centro de sus intereses ${ }^{126}$.

Aunque su producción se concentró sobre todo en el periodo de 1920-1923, la presencia en todos sus escritos de una naturaleza ético-política y el carácter militante sus ensayos, le permitió entrar en contacto con Gramsci, en principio por intereses literarios comunes, después por la colaboración, pedida por el mismo intelectual sardo, en Ordine Nuovo ${ }^{127}$. A pesar de esta cercanía con el mundo de la izquierda, Gobetti nunca participó en la actividad política y en la organización del Partido Comunista. Fueron el idealismo, las herencias de Croce y Labriola las que constituyeron la clave de su lectura del mundo obrero. El vio en los consejos de fábrica "la posibilidad de crear un nuevo sistema económico que puede, al final, resolver la difícil antítesis entre proteccionismo y liberalismo" 128 . A diferencia del economista liberal, Luigi Einaudi, no quería describir Marx no un simple economista, sino, en primer lugar, "el historiador (el estudioso de la lucha de clase en Francia) y el apóstol de la clase obrera" ${ }^{129}$.

A pesar de la superficialidad de esta breve caracterización de Gobetti, resultan claras las razones de la cercanía en el joven letrado turinés y Mariátegui. En su texto, hablando de las relaciones entre los dos, París sostiene que Mariátegui, a través de Gobetti "no hace sino hallar la lección austera de Croce" 130 . Pese al hecho de que el autor francés propone también algunas claves de lectura interesante acerca la relación intelectual entre los dos, esta visión nos parece un poco reductora. Para empezar, más allá de las herencias de Croce que caracterizaron el mundo de la época, Gobetti e Mariátegui compartían muchos más rasgos intelectuales. La religión, por ejemplo ${ }^{131}$. El mismo Mariátegui, hablando de las relaciones entre marxismo y materialismo, sostuvo que sería un gran error el suponer que "una concepción materialista del universo no sea apta para producir grandes valores espirituales". Según el peruano, tal como "la metafísica cristiana no ha impedido a Occidente grandes realizaciones materiales", así el materialismo marxista compendia todas las posibilidades de ascensión moral, espiritual y filosófica de nuestra época"132. La justificación a esta toma de posición derivó directamente de la obra de Piero Gobetti, que, según Mariátegui, "ha considerado este problema en términos de admirable justeza"133.

Siguiendo Gobetti, "el cristianismo trasportaba el mundo de la verdad en nosotros, en la intimidad del espíritu, indicaba a los hombres un deber, una misión, una redención". Por estos motivos, una vez abandonado el dogma cristiano, los hombres se han encontrados "más ricos de valores espirituales, más cocientes, más capaces de acción"134. Mariátegui, siempre apoyándose en el análisis de Gobetti, concluye que el problema contemporáneo era

\footnotetext{
${ }^{126}$ FerRerI, "Política y cultura en Piero Gobetti”, Studi Storici, Anno 11, No.2 (Apr.- Junio 1970), p. 333.

${ }^{127}$ Ibid., pp. 392-396.

128 VANEK, "Piero Gobetti and the Crisis of the Primo Dopoguerra", The Journal of modern History, Vol. 37, No.1 (Mar., 1965), p.7.

129 Ibid., p. 10.

${ }^{130}$ PARÍs, La Formación ideológica de José Carlos Mariátegui, p. 163.

${ }^{131}$ Otro tema, que no analizo en esto apartado, tiene que ver con la importancia de la educación de fábrica por los trabajadores.

132 "El idealismo materialista", en MARIÁTEGUI, Textos Básicos, p. 35.

133 Ibid., 32.

${ }^{134}$ Ibid., p. 34.
} 
"moral y político", porque "nuestra filosofía santifica los valores de la práctica. Todo se reduce a un criterio de responsabilidad humana [...]. El nuevo criterio de la verdad es la obra que se adecua a la responsabilidad de cada uno ${ }^{135}$.

No solamente en la herencia religiosa, sino también en la peculiar visión de Marxismo, anti-positivista y herético, Mariátegui se inspiró mucho en las obras de Gobetti. El último editorial escrito por Mariátegui por el aniversario de Amauta fue un agradecimiento al intelectual italiano:

Capitalismo o Socialismo. Este es el problema de nuestra época. No nos anticipemos a las síntesis, a las transacciones, que solo pueden operarse en la historia. Pensamos y sentimos como Gobetti que la historia es un reformismo más a condición de que los revolucionarios operen como tales. Marx, Sorel, Lenin, he ahí los hombres que hacen la historia ${ }^{136}$.

Como ya revisamos, Mariátegui no buscó en Gobetti solamente "algunos modelos, o sea [...] el modelo de una reconstrucción histórica que a Mariátegui parece directamente traducible a la realidad peruana" ${ }^{137}$ como sostiene París, sino mucho más de esto. A pesar de esta visión un poco parcial de las relaciones entre los dos, París individua dos puntos claves de las herencias de Gobetti: la importancia del texto Risorgimento senza eroi en la construcción de los Siete Ensayos ${ }^{138}$ y el rol del análisis económico gobettiano por el director de Amauta. Empezando con este último punto, París manifiesta su sorpresa en la decisión de tomar a Gobetti como referente económico, del momento que el autor italiano "parece más preocupado por la batalla de ideas o por la "batalla ideal" que por fundar sus análisis sobre un verdadero estudio económico, así fuera en los solos términos de la economía liberal clásica [...] en realidad, nada hay de economía en Gobetti ${ }^{139}$.

Por cierto, Gobetti no fue principalmente un economista, pero un sus juicios morales, políticos, filosóficos, estéticos e histórico la economía siempre jugó el papel principal. Tomando en cuenta la importancia del anti-positivismo y del idealismo que en la época caracterizaba no solamente el análisis marxista, sino también el liberal, resulta claro que la economía que Mariátegui dice apreciar en Gobetti, no es de entender como un análisis económico puro. Como dijo el mismo Mariátegui, el signo más distintivo de la modernidad y del realismo de Gobetti fue "la sagaz y constante preocupación por lo económico" que procede de una "autónoma y libérrima maduración de su pensamiento" ${ }^{140}$. La misma madurez que podemos ver en la evolución del pensamiento de Mariátegui. El mismo París, citando a Gobetti, subraya que su explicación del atraso económico estaba estrechamente relacionada, en el caso italiano, con la cultura política. Según Gobetti:

\footnotetext{
${ }^{135}$ Ibid., p. 37.

${ }^{136}$ MARIÁTEGUI, “Aniversario y balance”, Amauta 17, Lima, Setiembre 1928.

${ }^{137}$ PARÍs, La Formación ideológica de José Carlos Mariátegui, p. 159.

${ }^{138}$ Esta similitud es subrayada también por Núñez, según el cual la idea original de escribir los artículos de "Peruanicemos el Perú" y que después, estructurados, constituyen los capítulos del libro Siete ensayos de Interpretación de la realidad peruana partió de la lectura detenida de los libros de Gobetti, estructurados de semejante manera y aparecidos poco tiempo después de la muerte de su autor y minuciosamente leídos y comentados por Mariátegui. Véase NúÑEZ, La experiencia europea de José Carlos Mariátegui, p. 36.

${ }^{139}$ PARÍs, La Formación ideológica de José Carlos Mariátegui, p. 161.

${ }^{140}$ MARIÁTEGUI, El alma matinal, p. 136.
} 
La economía nacional está todavía demasiado retrasada, el país es pobre y no concede tregua a los individuos no les permite la dignidad de ciudadano [...] La aristocracia industrial y obrera, a la cual está ligada la posibilidad de una transformación moderna en Italia, está apena en su nacimiento y no logra distinguirse de las sobreposiciones y confusiones parasitarias, no logra vencer el pauperismo y el diletantismo ${ }^{141}$.

Aunque París no profundiza las posibles conexiones entre el concepto de economía de Gobetti y Mariátegui volviendo otra vez al crocianismo del intelectual italiano, nos parece necesario precisar esta cuestión. Hablando de la revolución liberal, Gobetti señala de manera clara cómo "a causa del atraso de la economía nacional" Italia es un país pobre y el hecho que "dos tercios de la población comparten la suerte de una agricultura atrasada" condenará al país "por muchos años a no devenir moderno" ${ }^{142}$. El mismo Mariátegui relaciona el retraso económico con la presencia de líderes políticos "espiritual y orgánicamente inadecuados para dirigir un trabajo de reconstrucción económica", con la consecuencia que el sistema económico peruano, que ha mantenido la agricultura como actividad principal del país, destinará el país a quedarse en un "sistema semi-feudal"143.

Estas dos citas son importantes solamente para entender el motivo de la importancia de la economía para los dos autores. No es un análisis económico lo que los dos buscan, sino subrayar cómo desequilibrios y atrasos económicos impactan sobre las posibilidades de modernización de la nación. Después de esta puntualización, volvemos a la otra relación entre los dos intelectuales: la herencia de Risorgimento senza eroi en los Sietes Ensayos.

Antes de empezar es necesaria una aclaración: tanto Mariátegui como Gobetti escriben esta obra pensando en la situación que sus países vivían. En otras palabras, el italiano, cuando cuestiona el Risorgimento, lo hace a partir de la Italia Mussoliniana, abogando por una "solución integral y decisiva" a la "crisis revolucionaria italiana"144, donde el proletariado turinés tendría que jugar un papel protagónico. El peruano, hablando de la revolución de la Independencia peruana, se refiere por cierto a la actual situación de Perú, mirando a los indios peruanos como fuerza revolucionaria, fuerza que esté irrumpiendo en la historia.

Gobetti, empezando por la idea que el proceso del Risorgimento todavía no ha acabado, se enfrenta con la gran problemática de la creación de una clase política con clara conciencia de sus tradiciones históricas y de las necesidades sociales que tiene el pueblo. Es decir, el estado moderno no puede estar sin la contribución de las masas obreras y campesinas que recen "ingresan a la historia" y tienen que relacionarse con las élites liberales, con la clase empresarial. El liberal italiano se propuso mirar el resurgimiento italiano "sin héroes", un "resurgimiento de los heréticos, no de los profesionales"145. El estado demo-liberal en Italia era, según Gobetti, el resultado de una mezcla entre la

\footnotetext{
141 “La Nostra cultura política”, en GoBeTti, Scritti politici, 458, cit. en París, La Formación ideológica de José Carlos Mariátegui, p. 164.

${ }^{142}$ GobetTI, La Rivoluzione Liberale. Saggio sulla lotta política in Italia, p. 36.

143 "Esquema de la Evolución Económica", MARIÁtegui, Textos Básicos, p. 47.

${ }^{144}$ Citado por MARIÁTEGUI, El alma matinal, p. 59.

${ }^{145}$ GoBetTI, La Revolución Liberal, Ensayo acerca de la lucha política en Italia, p. 122.
} 
mentalidad realista y europea de las regiones industriales del Norte y los gustos cortesanos demagógicos de las regiones campesinas del sur. El problema del Risorgimento italiano fue "construir una unidad que fuese unidad de pueblo"; problema que permanece irresoluto porque la conquista de la independencia no ha sido sentida "como obra fatigosa y autónoma de formación activamente espontánea" donde el proletariado no fue el protagonista, sino el resultado de juegos políticos sujetos a "las leyes del oportunismo y la transacción" 146 desarrolladas por las clases dirigentes. En definitiva, según Gobetti, la revolución del Risorgimento "no fue revolucionaria, no creó al estado"147.

Como bien subraya París, el modelo propuesto por Gobetti, o sea "antes que las ideas los hechos y que los elementos que introducen al presente contribuyen a explicarlo"148, fue traducido por Mariátegui a la realidad peruana. Mariátegui, tributario de estos análisis, piensa el proceso de conformación nacional remontándose a los orígenes del "pecado original de la conquista"149. Fue la herencia colonial española, donde "la clase media no buscaba un cambio, una iniciativa propia dentro de un marco de libre competencia", sino que reinaba la "empleomanía y el recurso al pequeño empleo estatal" 150 , que impidió al propietario criollo "entender netamente lo que distinguía el capitalismo de la feudalidad"151. La guerra de independencia, conducida por "jefes militares y caudillos espiritual y orgánicamente inadecuados para dirigir un trabajo de reconstrucción nacional" no cambió esta situación, y la revolución fue entonces una revolución truncada.

Si por Gobetti los "heréticos" eran los sectores proletarios de la población, para Mariátegui son los indios. Relocalizando la cuestión indígena como centro de gravedad del problema nacional, Mariátegui ataca la creación de un nacionalismo por parte de la sociedad oligárquica, nacionalismo que ha excluido los indios de este proceso, concluyendo que "la unidad peruana está por hacerse [...]. En el Perú el problema de la unicidad es mucho más hondo porque no hay aquí que resolver una pluralidad de tradiciones locales o regionales, sino una dualidad de raza, lengua y sentimiento"152.

Tanto el caso italiano como el peruano, el problema de construir una unidad que fuese pueblo se quedó sin solución.

\section{Mariátegui y Tilgher: entre "mito", crisis de la democracia y del modelo liberal}

Entre los diferentes intelectuales italianos que jugaron un papel importante en la formación de Mariátegui, cabe destacar a Adriano Tilgher. El filósofo napolitano, aunque no ejerció sobre el intelectual peruano el mismo ascendente de Croce, Gramsci, Labriola y

\footnotetext{
146 Gobetti atacó la clase media culpable de preferir un espíritu de conciliación y un general "parasitismos" a la reivindicación de la propia autonomía. Véase GOBETTI, La Revolución Liberal, Ensayo acerca de la lucha política en Italia, p. 130.

${ }^{147}$ GOBETTI, La Revolución Liberal, Ensayo acerca de la lucha política en Italia, p. 135.

148 PARís, La Formación ideológica de José Carlos Mariátegui, p. 154.

${ }^{149}$ FUNES, Salvar la nación. Intelectuales, cultura y política en los años vente latinoamericanos, p. 130.

${ }^{150}$ MARIÁTEGUI, Siete Ensayos de Interpretación de la realidad Peruana, p.62.

${ }^{151}$ Ibid., p. 70.

152 Ibid., p. 184.
} 
Gobetti, entró en contacto con Mariátegui y, como bien señala Diego Meseguer ${ }^{153}$ no podemos subestimar su herencia, ya que ésta se puede apreciar en varios análisis de Mariátegui, sobre todo los que tienen que ver con la lectura del intelectual peruano acerca de la interpretación de la agonía del mundo liberal y del parlamentarismo, de las causa de la guerra mundial, de la crisis irreversible del modelo capitalista y de un primer acercamiento al concepto de mito.

Tilgher se apasionó, como Mariátegui, por el arte y la obra de Pirandello, definido como "verdadera dramaturgo de los nuevos tiempos" capaz, con su relativismo y escepticismo de representar la crisis europea y la "falta de fe" del capitalismo" ${ }^{154}$. Su fascinación por la estética, el romanticismo de matriz cristiana, por un pensamiento voluntarista y activista hijo del idealismo crociano y, al mismo tiempo, su defensa de la necesidad de una fuerza renovadora capaz de romper la situación de crisis que vivía la democracia parlamentaria, tuvieron sin duda un impacto relevante en el joven esteta peruano.

En general las similitudes entre los dos intelectuales se sitúan en el marco de la triple crisis que el sistema liberal estaba viviendo al comienzo de los años veinte: crisis económica, política y artística. La decadencia del occidente, como fue definida por Oswald Spengler, autor conocido tanto por Tilgher como por Mariátegui, llevó el filósofo italiano a declarar muerta la civilización capitalista. La matanza en la Primera Guerra Mundial y la precaria situación económica no dejaban alguna duda: "la civilización de la Europa Moderna en las llamas y en la sangre. A esta civilización seguirá seguramente un nuevo y esplendido renacimiento" 155 . Decadentismo y fe casi religiosa en una exegesis de la humanidad fueron, como ya hemos visto, temas queridos por el Mariátegui de la «edad de la piedra».

La primera influencia del pensamiento de Tilgher sobre Mariátegui, la podemos apreciar en la conceptualización de democracia y capitalismo. Tilgher, que vivía en carne propia la situación de crisis de la Italia de la posguerra, atacó duramente todas las contradicciones del sistema democrático, un "régimen que afirma la igualdad política de todos los ciudadanos, cual siquiera sean sus desigualdades económicas", caracterizando la democracia contemporánea como "régimen característico de la sociedad capitalista" porque su rasgo principal era la "coexistencia de la igualdad política y de la desigualdad económica" ${ }^{156}$. En Italia, conforme a lo planeado por Tilgher, la posibilidad de utilizar el parlamento como órgano superior a los conflictos de clase, capaz de buscar un compromiso entre las diferentes fuerzas centrifugas presentes en la sociedad era difícil. La imposibilidad de pacificar la situación italiana derivaba, en última instancia, de la fuerza creciente del

\footnotetext{
${ }^{153}$ Meseguer es el único, entre los estudiosos de Mariátegui, que subraya este influjo. A pesar del demasiado énfasis sobre la influencia idealista de Mariátegui y de la falta de una profundización del pensamiento de Tilgher, su sugerencia es interesante y pertinente. Para un análisis sobre las relaciones entre Mariátegui y Tilgher Véase Illán MesegueR, José Carlos Mariátegui y su pensamiento revolucionario, p. 39 y pp.80-82.

${ }^{154}$ Ibid., pp. 21-22. Es curioso subrayar como el mismo Mariátegui definió Pirandello como el escritor que mejor representó el alma desencantada de la civilización occidental: "Pirandello pertenecía a un mundo que anda buscando su yo perdido. El escepticismo, el relativismo, el subjetivismo filosófico de este mundo". Véase "Marinetti y el futurismo", en MARIÁTEGUI, La escena contemporánea, p.87.

155 TILGHER, La crisi mondiale e saggi critici su marxismo e socialismo, p. 21.

156 Ibid., p. 151.
} 
movimiento obrero y de la lucha de clase, que ya dominaba el panorama italiano y estaba destinada a quitar legitimidad al órgano parlamentario.

Las primeras observaciones de Mariátegui sobre el parlamentarismo, la democracia y el capitalismo en Italia, comparten muchos aspectos con el pensamiento de Tilgher. Según el intelectual peruano el parlamento era una institución destinada a desaparecer, porque ya había cumplido su misión histórica. Mariátegui, criticando la nueva democracia del socialista Giorgio Amendola, que aceptó colaborar con los liberales en el gobierno de unidad nacional de 1921, escribió que "siendo sorda a todas las notificaciones históricas" y siendo expresión de la "recalcitrante mentalidad de la pequeña burguesía" la democracia estaba destinada a desaparecer ${ }^{157}$. No solamente la democracia, sino el mismo Parlamento fue objetivo de la aguada crítica de Mariátegui, quien lo describió como instituciones obsoletas, incapaces de ser aceptado como árbitro en "la lucha de la clase proletaria para remplazar la clase burguesa"158. La crítica hecha por el intelectual peruano al sistema democrático tenía, como en Tilgher, el mismo énfasis sobre los aspectos irracionales, casi místicos podremos decir. Era, para Mariátegui, la política desarrollada por los pequeños burgueses la causa principal de la crisis. Estos, incapaces de adaptar la democracia a la nueva realidad histórica, causaron un deterioro en la "democracia como forma", olvidándose del papel primigenio de la "democracia como idea, como espíritu ${ }^{159}$.

Otro paralelo entre los dos pensadores tiene que ver con la descripción los eventos bélicos del primer conflicto mundial. En 1921 Tilgher escribió cómo la guerra mundial fue el resultado del choque entre "un imperialismo ya firme y desarrollado como el inglés [...] contra otro que aspira a conquistar un lugar al sol"160. También Mariátegui vio las causas más remotas de la guerra en "el desarrollo del industrialismo británico y del industrialismo alemán", con el fin de conquistar los mercados de las colonias para aumentar la producción ${ }^{161}$. No solamente las causas, sino las actitudes de los dos bloques durante la guerra son analizadas de manera muy parecida por parte de los dos intelectuales.

Tanto por Tilgher cuanto por Mariátegui la victoria de la guerra por parte de los aliados dependió de factores psicológicos más que de factores militares. Tilgher sustenta que, para las fuerzas democráticas, el conflicto fue casi como una "guerra de religión" bautizado por Wilson con la "agua santa del ideal"162. Fue la fuerza de los sentimientos colectivos creados por los gobiernos aliados adentro de cada país que permitió la creación de mitos colectivos -en Francia el de la Democracia y en Inglaterra, la defensa de las pequeñas naciones en contra del agresivo imperialismo alemán- a permitir la victoria en el conflicto.

\footnotetext{
157 A pesar de esto Mariátegui tiene una buena impresión de Amendola, que, "a diferencia de los políticos transformistas" apoyaba una forma "práctica, no retórica de democracia". Pero "su psicología de hombre de combate y su defensa del parlamentarismo" le impidieron ver la crisis del sistema liberal. Véase "Amendola y la batalle liberal en Italia", en MARIÁTEGUI, La Escena contemporánea, pp. 66-69.

158 Véase MARIÁTEGUI, El alma matinal, pp. 34-35.

159 Ibid., p. 31.

160 Ibid., p. 33.

161 Mariátegui vio responsabilidades también en las políticas económicas proteccionistas de los países europeos, véase, "Segunda Conferencia”, en MARIÁTEGUI, "Historia de la crisis mundial, p. 67.

162 TILGHER, La crisi mondiale e saggi critici su marxismo e socialismo, p. 32.
} 
El mismo Mariátegui retomó esta interpretación. Describiendo las diferentes actitudes entre las naciones en guerra, subrayó que los mitos de libertad, democracia y paz constituyeron el elemento vital de la victoria aliada, el verdadero motor de la victoria: "la guerra probó una vez más el valor del mito. Los pueblos capaces de victoria fueron los pueblos capaces de un mito multitudinario"163.

Siguiendo con este concepto de mito, resulta interesante comentar cómo el mismo concepto fue utilizado por los dos para explicar la crisis del capitalismo. Según Tilgher la civilización capitalista había perdido "su mito", porque la guerra había dado el golpe de gracias al historicismo y el evolucionismo típicos de la visión del mundo capitalista. Perdiendo su "fe absoluta en su voluntad de poder" la civilización capitalista estaba destinada a desaparecer, porqué privada de su "fuerza movilizadora [...] de su mito"164. Mariátegui, hablando de la civilización burguesa, subrayó que ésta estaba perdiendo su mito liberal. ¿Quién mejor que el primer ministro inglés, Lloyd Goerge, falto de "fanatismo, dogmatismo y pasión"165 podía representar esta crisis? Empezando por estas consideraciones el peruano planteó su visión de "mito como verdadero motor de la historia" capaz de "mover al hombre". Sin mito, según Mariátegui, la existencia del hombre no tiene ningún sentido histórico. La historia la hacen los hombres poseídos e iluminados por una experiencia súper humana"166.

La polémica anti-racionalista de Mariátegui se concretó en una violenta arenga en contra la razón positivista también en los años siguientes. Fue en 1925, con la publicación del famoso artículo "El Hombre y el Mito" 167 , que el directo de Amauta estructuró de manera mejor una idea que, como hemos visto, ya estaba presente en algunas de sus reflexiones. Según Mariátegui entonces era la razón que había "extirpado del alma de la civilización burguesa los residuos de sus antiguos mitos" y, sin "fe, sin esperanza" esta particular civilización estaba destinada a desaparecer, y los burgueses a ser simples hombres que constituyen el "coro anónimo del drama"168. La tarea de hacer la historia residía en "los hombres poseídos e iluminados por una creencia superior, por una esperanza supe humana". La posesión de un mito era, según Mariátegui, la mayor diferencia entre la burguesía y el proletariado: "La burguesía no tiene ya mito alguno. Se ha vuelto incrédula, escéptica, nihilista [...]. El proletariado tiene un mito: la revolución social. [...] La fuerza de los revolucionarios no está en su ciencia: está en su fe, en su pasión, en su voluntad. Es una fuerza religiosa, mística, espiritual. Es la fuerza del Mito ${ }^{169}$. En concreto, ¿qué es el mito?, ¿cuál es su esencia? ¿Cuál es el nuevo mito que dirige la praxis del proletariado?

Mariátegui nunca dio una definición de mito, sino que entregó una serie de epítetos que lo describen. Él lo caracterizaba, al igual que Tilgher, como algo que se sitúa más allá

\footnotetext{
163 MARIÁtegui, El Alma Matinal, p. 19.

164 TILGHER, La crisi mondiale e saggi critici su marxismo e socialismo. p. 200.

165 A quienes lo definen como político nostálgico de una posición revolucionaria, Mariátegui contesta que este juicio está hecho "a base de datos superficiales de la personalidad de Lloyd George. Lloyd George no tiene aptitudes espirituales para ser un caudillo revolucionario ni un caudillo reaccionario". Véase "Lloyd George", en MARIÁTEGUI, La escena contemporánea, p. 54-57.

166 Mariátegui, El alma matinal, p. 19.

${ }_{167}$ Publicado en El Mundial, Lima, 16 de enero de 1925. Véase MARIÁTEGUI, Textos Básicos, pp. 9-13.

168 Ibid., p.10.

169 Ibid., p 12.
} 
de la razón, una fe, una esperanza que, aunque no tiene fundamento racional, tiene que ser aceptada. La diferencia entre el uso del mito por los dos autores residía en la importancia como posible motor de una revolución proletaria, porque "El hombre contemporáneo tiene necesidad de fe. Y la única fe, que puede ocupar su yo profundo, es una fe combativa"

En Defensa del marxismo Mariátegui, polemizando con el texto de Henry De Man, intelectual que ignora y elude la emoción, el pathos revolucionario" ${ }^{171}$, reivindicó la función de la fe como una labor activa, fundamental en el propiciar la acción del hombre: "la teoría de los mitos revolucionarios, que aplica al movimiento socialista la experiencia de los movimientos religiosos, establece las bases de una filosofía de la revolución, profundamente impregnada de realismo psicológico y sociológico" ${ }^{172}$. O sea, Mariátegui aplicó su concepción de mito al naciente movimiento socialista peruano, mito como fuerza movilizadora, mito como síntesis de experiencias previas, mito como nueva base de una particular filosofía, la filosofía de la revolución.

\section{Apuntes finales}

Como hemos visto en este texto, la experiencia italiana dejó a Mariátegui una gran capital de herencias intelectuales y políticas. A pesar de la importancia de las influencias de varios intelectuales italianos no pretendo plantear que las ideas y los trabajos futuros de Mariátegui fueron consecuencias directas de cuanto aprendió en Italia. El pensador peruano, en sus años sucesivos al "exilio dorado", se caracterizó por un continuo desarrollo creador y un análisis de matriz marxista capaz de abarcar los diferentes problemas de la realidad peruana y proponer soluciones originales para la clase proletaria y campesina de su país.

Lo que sí quiero subrayar es el profundo cambio que el viaje a Italia dejó en el peruano, ya que antes de su viaje, y a pesar del continuo interés por los problemas sociales y políticos de Perú, el nivel de desarrollo teórico del pensamiento intelectual de Mariátegui era muy diferente al del Mariátegui maduro. La importancia de algunos temas típicos de la «edad de la piedra», como el vanguardismo futurista o la atención hacia movimientos religiosos, lo llevó, a describir con palabras de admiración personajes como D’Annunzio y Don Luigi Sturzo, que poco tenían que ver con el mundo de la izquierda y el marxismo. A este propósito es curioso destacar que en sus Cartas de Italia Mariátegui trate de manera marginal y un poco superficial los eventos que caracterizaron el mundo socialista italiano de la época. Más interesado por el voluntarismo, el mito de la acción y el idealismo del futurismo de matriz d'annunziana y por la dimensión popular y el espiritualismo cristiano de Sturzo, el director de Amauta no ofreció un análisis original alrededor de la subida del fascismo o de las luchas intestinas al mundo de la izquierda.

Las estrechas relaciones con Gobetti, el conocimiento de los textos de Labriola, Croce, Gramsci y Tilgher, causaron seguramente una gran reflexión y un cambio de perspectivas en el joven peruano. Sin duda el voluntarismo mariateguiano y su sello antireformista, ya presentes antes del viaje a Italia, encontraron en la península el suelo

\footnotetext{
${ }^{170}$ MARIÁTEGUI, El alma matinal, p. 18.

171 "Henri de Man y la "crisis" del marxismo", en MARIÁTEGUI, Defensa del Marxismo, p. 19.

172 Ibid., p. 17.
} 
perfecto para poder dar un pase más allá, asimilando nociones de marxismo y otras ideas que serán de importancia fundamental en los estudios sucesivos de Mariátegui. En síntesis, ¿cuáles fueron las ideas con las que Mariátegui se casó en su viaje a Italia? ¿Quién fueron los autores que más influyeron sobre su pensamiento?

En primer lugar, hemos visto las similitudes entre el intelectual peruano y la escuela marxista de Labriola y Croce. Fue en particular Labriola, el primer marxista italiano, quien dejó una influencia fuerte en las obras de Mariátegui. La importancia de un marxismo que debía atenuar el demasiado énfasis en el economicismo y recuperar la importancia del elemento histórico fue la primera base del marxismo mariateguiano. Marxismo más abierto, definido herético por algunos ortodoxos, pero seguramente no dogmático, orientado más hacia la acción que práctica. Labriola no solamente heredó al peruano esta forma de marxismo, sino que, también, la importancia de la dimensión ética en la acción política y la consecuente importancia de la educación de la clase obrera. La necesidad de sustituir a la corrupción de los políticos la pasión, llevó, a los dos autores a plantear la función ética del socialismo.

El segundo autor analizado fue Gramsci. A pesar de la falta de un estudio específico sobre la cercanía intelectual entre los dos autores, he tratado plantear algunas posibles hipótesis acerca de la herencia intelectual dejada a Mariátegui por el sardo en sus años de juventud. Más allá del mismo esquema de marxismo, Mariátegui retomó de Gramsci la interpretación del fenómeno fascista, descrito como movimiento contrarrevolucionario de la pequeña burguesía y el concepto que he definido "práctico" de la autonomía del socialismo, o sea la necesidad de la construcción de una fuerza socialista que fuese autónoma y controlada por las fuerzas proletarias. Más interesante es la similitud entre la caracterización del problema del sur Italia hecha por Grasmci y la de Perú hecha por Mariátegui en los Siete Ensayos. Los dos se enfocaron en el problema de la territorialidad, sobre dos países (Italia y Perú) en donde los dualismos económicos, sociales y culturales, podían ser superados con la fuerza del ideal.

Las relaciones ente Mariátegui y Gobetti han ocupado la tercera parte de mi análisis. La profunda amistad y la estima intelectual que Mariátegui tenía por el liberal turinés no son una novedad. A pesar de esto es interesante subrayar que los dos se caracterizaron por una común atención hacia la religión y que sus análisis trataron temas muy parecidos. La caracterización del elemento económico como motivo de atraso de los respetivos países, la presencia de un movimiento de unidad nacional incompleto, que no incorporó los elementos populares (sin héroes dijo Gobetti) y sus consecuencias en el proceso de construcción de la nación fueron temas, elaborados por Gobetti, que sirvieron como esquema por el sucesivo análisis de Mariátegui sobre la realidad peruana.

Para terminar, la herencia de Adriano Tilgher. Relación descuidada por los especialistas del tema ofreció algunas sugerencias para futuras investigaciones. La común pasión para el mundo de la literatura, el decadentismo, la importancia de los elementos irracionalistas y espiritualista del italiano dejaron una impresión tangible en Mariátegui. La crisis del sistema democrático liberal que había perdido su espíritu, la importancia del ideal y la fuerza movilizadora del mito fueron temas compartidos por los dos autores.

A pesar del hecho que, como ya he mencionado, el desarrollo creador de Mariátegui fue capaz de elaborar una visión original y personal de los problemas de su país, fue también gracias a estos fundamentos que, una vez de vuelta a Perú, el director de Amauta 
pudo dedicarse al proceso de rescate de los indios y del proletariado peruano, con el fin de construirse una "creación heroica" del socialismo peruano.

\section{Bibliografía}

Revista

Amauta, 1928-1930

Libros

ARICÓ, José, Mariátegui y los orígenes del marxismo latinoamericano, 60 cuadernos de pasado y presente, México, Ediciones Pasado y Presente, 1978.

----------Nueve Lecciones sobre economía y política en el marxismo, México, El Colegio de México, 2011.

Burga, Manuel, Flores Galindo, Alberto, Apogeo y crisis de la República Aristocrática, Lima, Ediciones Rikchay Perú, 1980.

Croce, Benedetto, Conversazioni critiche, Bari, Edizioni Laterza, 1950

------, Filosofia e Storiografia, Bari, Edizioni Laterza, 1949

-Il concetto della storia, Bari, Edizioni Laterza, 1960

----Materialismo histórico y economía marxista, Buenos Aires, Ediciones Imán,

1942.

Flores Galindo, Alberto, La Agonía de Mariátegui: la polémica con la Komintern, Lima, Centro de Estudios y Promoción del Desarrollo, 1980.

FunES, Patricia, Salvar la nación. Intelectuales, cultura y política en los años vente latinoamericanos, Buenos Aires, Prometeo Libros, 2006.

GobetTI, Piero, La Revolución Liberal, Ensayo acerca de la lucha política en Italia, México, FLACSO, 2008.

GRAMSCI Antonio, La Questione meridionale, Roma, Editori Riuniti, 1966.

Cuadernos de la cárcel, los intelectuales y la organización de la cultura, México, Editor Juan Pablos, 1975.

- Cuadernos de la cárcel, notas sobre Maquiavelo, sobre política y sobre el estado moderno, México, Editor Juan Pablos, 1975.

-Escritos políticos (1917-1933), México, Siglo Veintiuno Editores, 1981.

Illán MeSEGUER, Diego, José Carlos Mariátegui y su pensamiento revolucionario, Lima, Instituto de Estudios Peruanos, 1974.

LABRIOLA, Arturo, Del materialismo histórico, México, Editor Grijalbo 1971.

-------------, La concezione materialista della storia, Bari, Editore Laterza, 1969.

, Reforma y revolución social: la crisis práctica del Partido Socialista, Valencia,

Editores F. Sempere y Compañía, sin fecha.

MARiátegui, José Carlos, Cartas de Italia, Lima, Editora Amauta, 1969.

-, Defensa del Marxismo, Lima, Editora Amauta, 1959.

Amauta, 1964.--, El Alma Matinal y otras estaciones del hombre de hoy, Lima, Editora

Amauta, 1964.

-Escritos juveniles. La edad de la piedra (Compilación de Alberto Tauro), tomo I, Lima, Editora Amauta, 1994.

, Historia de la crisis mundial, Lima, Editora Amauta, sin fecha.

--------, La Escena contemporánea, Lima, Editora Amauta, 1967. 
Ediciones Solidaridad, 1969.

Siete Ensayos de Interpretación de la realidad peruana, México, Textos Básicos, México, Fundo de Cultura Económico, 1995.

Miró, César, Mariátegui, el tiempo y los hombres, Lima, Biblioteca Amauta, 1989.

MELIS, Antonio; Dessau, Adalbert; Kossok, Manfred, Mariátegui, tres estudios, Lima, Biblioteca Amauta, 1971.

MoreTiC, Yerko, José Carlos Mariátegui. Su Vida e ideario. Su concepción del realismo, Santiago de Chile, Ediciones de la Universidad Técnica del Estado, 1970.

NúÑEZ, Estuardo, La experiencia europea de José Carlos Mariátegui y otros ensayos, Lima, Amauta, 1978,

PARIS, Robert, La formación ideológica de José Carlos Mariátegui, Ediciones Pasado y Presente, México, 1981.

QuiJANO, Aníbal, Introducción a Mariátegui, Ediciones Era, México, 1981.

RouILlon, Guillermo, Bio-bibliografía de José Carlos Mariátegui, Lima, Universidad Nacional Mayor de San Marcos, 1963.

SALMIERI Stefani, PIGNATO Rosario Gramsci e la formazione dell'uomo. Itinerari educativi per una cultura progresista, Acireale, Editore Bonanno, 2008.

SAlvatorelli, Luigi, MIRA, Giovanni Storia d'Italia nel periodo fascista, Torino, Einaudi Editore, 1974.

TILGHER, Adriano La crisi mondiale e saggi critici su marxismo e socialismo, Bologna, Editore Zanichelli, 1921.

TogLiATti, Palmiro Il Partito Comunista Italiano, Roma, Editori Riuniti, 1958.

ZaPATA, Francisco, Ideología y política en América Latina, México, El Colegio de México, Centro de Estudios Sociológicos, 1990.

Artículos

ALATRI, Luigi "Luigi Sturzo nel centenario della nascita", en Studi Storici, No.1 (Jan-Mar., 1972), pp. 199-215.

ARICó, José "Mariátegui y la formación del partido socialista en Perú", en Socialismo y Participación N.11.

COlBert JR, James G., "Labriola, Croce, Anti-Croce", en Studies in Soviet Thought, vol. 24, No.2 (Aug. 1982), pp. 147-160.

ConchA, Jaime, "Mariátegui y su crítica al latifundio", en Revista Casas de las América, N. 140, La Habana 1983.

DETTI, Tommaso, "Protagonisti e alternative del Biennio Rosso", en Studi Storici, Anno 13, No.1 (Jan. -Mar., 197), pp. 191-198.

GERRATANA, Valentino, "Antonio Labriola e la política”, en Studi Storici, Anno 1926, No.3 (Jul.Sept., 1985), pp. 565-580.

MELIS, Antonio, "El debate sobre Mariátegui: Resultados y problemas", en Revista de Crítica Literaria Latinoamericana, Año 2, No.4 (1976), pp. 123-132.

"Mariátegui, primer marxista de América", Cuadernos de cultura latinoamericana

N.95, Centro de Estudios Latinoamericanos, UNAM, 1979.

PROCACCI, Giovanna, "Popular protest and labour conflict in Italy", 1915-1918”, en Social History, Vol. 14, No.1 (Jan. 1989), pp. 31-58.

SICILIANI DE CUMIS, Nicola, "Per una "Autobiografia" intellettuale e política di Antonio Labriola", en Studi Storici, Anno 26, Oct-Dic 1985, pp. 775-787.

SPRIANO, Paola, “Gramsci e Gobetti”, en Studi Storici, Anno 17, No.2 (Aprile- Giugno 1976), pp. 69-93.

URBINATI, Nadia, "Le passioni e la política. Il meridione di Antonio Gramsci”, en Studi Storici, Anno 37, No.2, (Aprile-Giugno 1996), pp. 465-487. 
VANEK, Wilda M., "Piero Gobetti and the Crisis of the Primo Dopoguerra", The Journal of modern History, Vol. 37, No.1 (Mar. 1965), pp. 1-17.

ZANGHERI, Renato, "Il marxismo di Antonio Labriola. Un riesame", en Studi Storici, Anno 44, No.1 (Jan. -Mar., 2003), pp. 153-163.

Sitios Internet: www.antoniograsmci.org 